\title{
Current understanding on pharmacokinetics, clinical efficacy and safety of progestins for treating pain associated to endometriosis
}

\section{Fabio Barra, Carolina Scala \& Simone Ferrero}

To cite this article: Fabio Barra, Carolina Scala \& Simone Ferrero (2018): Current understanding on pharmacokinetics, clinical efficacy and safety of progestins for treating pain associated to endometriosis, Expert Opinion on Drug Metabolism \& Toxicology, DOI: 10.1080/17425255.2018.1461840

To link to this article: https://doi.org/10.1080/17425255.2018.1461840

Accepted author version posted online: 04 Apr 2018.

Submit your article to this journal $₫$

Q View related articles $\llbracket$

View Crossmark data ¿ 
Publisher: Taylor \& Francis

Journal: Expert Opinion on Drug Metabolism \& Toxicology

DOI: $10.1080 / 17425255.2018 .1461840$

Current understanding on pharmacokinetics, clinical efficacy and safety of progestins for treating pain associated to endometriosis

Fabio Barra $^{1,2}$, Carolina Scala ${ }^{1,2}$, Simone Ferrero ${ }^{1,2}$

\section{Institutions:}

${ }^{1}$ Academic Unit of Obstetrics and Gynecology, Ospedale Policlinico San Martino, Largo R. Benzi 10, 16132 Genoa, Italy

${ }^{2}$ Department of Neurosciences, Rehabilitation, Ophthalmology, Genetics, Maternal and Child Health (DiNOGMI), University of Genoa, Italy

\section{Corresponding Author:}

Simone Ferrero MD, PhD; Academic Unit of Obstetrics and Gynecology, IRCCS AOU San Martino - IST, Largo R. Benzi 10, 16132 Genoa, Italy

Telephone 01139010511525

Mobile 011393477211682

Fax 01139010511525

E-mail: simone.ferrero@unige.it

\section{Funding}

This paper was not funded.

\section{Declaration of interest:}

The authors have no relevant affiliations or financial involvement with any organization or entity with a financial interest in or financial conflict with the subject matter or materials discussed in the manuscript. This includes employment, consultancies, honoraria, stock ownership or options, expert testimony, grants or patents received or pending, or royalties. Peer reviewers on this manuscript have no relevant financial or other relationships to disclose 


\section{Abstract \\ Introduction}

Endometriosis is a chronic estrogen and progestogen responsive inflammatory disease associated with pain symptoms and infertility. The medical therapy of endometriosis aims to induce decidualization within the hormonally dependent ectopic endometrium, and it is often administered to ameliorate women' pain symptoms or to prevent post-surgical disease recurrence. A variety of progestins have been used in monotherapy for the medical management of women with endometriosis.

\section{Areas covered}

This review aims to offer the reader a complete overview of pharmacokinetic (PK) and clinical efficacy of progestins for the treatment of endometriosis.

\section{Expert opinion}

Each progestin has a distinct PK parameters and pharmacodynamics affinity not only for progesterone receptor, but also for other steroid receptors, such as estrogen, androgen, and glucocorticoid. Moreover, progestins can also be delivered in different formulations. All these characteristics influence their final biological effect. Randomized, controlled, non-blinded studies support the use of oral progestin-only treatment for pelvic pain associated with endometriosis. Currently, the only two progestins approved by Food and Drug Administration (FDA) for the treatment of endometriosis are norethindrone acetate (NETA) and depot medroxyprogesterone acetate (DMPA).

Keywords: Endometriosis, progestins, medical therapy, norethindrone, dienogest, depot medroxyprogesterone, LNG-IUD 


\section{Article Highlights}

- Progestins have been increasingly and successfully employed as monotherapy for the treatment of endometriosis related pain symptoms, being efficacious and well tolerated in several randomized, controlled, non-blinded studies;

- Progestins have good a long-term tolerability profile. However, the main drug-related AEs are spotting and breakthrough bleeding, depression, breast tenderness and fluid retention;

- Currently only norethindrone acetate (NETA) and depot medroxyprogesterone acetate (DMPA) as monotherapy have been approved by the Food and Drug Administration (FDA) for the treatment of endometriosis;

- NETA is one of the most studied progestin for the treatment of endometriosis. Its good safety-profile and efficacy in improving endometriosis-related pain do NETA a suitable medical option among first-line therapies;

- One of the best long-term medical treatment for endometriosis is the LNG-IUD. In comparison with the systemic administration, its local release of progestin has similar or improved efficacy, particularly evident on the local target organ, with reduced systemic AEs.

- Further studies are needed to clarify the effect of long-term treatment with progestins on bone mineral density (BMD). 


\subsection{Introduction}

Endometriosis is a chronic estrogen and progestogen responsive inflammatory condition defined by the presence of glands and stroma, which affects about $6-10 \%$ of women of reproductive age [1]. Endometriosis is distinguished in three different phenotypes: ovarian endometrioma, superficial peritoneal endometriosis, and deep infiltrating endometriosis (DIE). Clinically, endometriosis can cause both pain symptoms (dysmenorrhea, deep dyspareunia, chronic pelvic pain and dyschezia) and infertility [2]. The surgical excision of endometriotic implants improves pain symptoms, but it may be associated with intestinal, urological and vascular complications. Furthermore, endometriosis-related pain may recur after surgery and patients may not accept a second operation. In addition, some patients desire to delay or avoid surgery preferring a long-term medical therapy to control their symptoms [3].

Medical treatment of endometriosis acts inducing decidualization and eventually atrophy within the hormonally dependent ectopic endometrium [4]. It aims to ameliorate pain symptoms as long-term therapy in women who do not undergo surgery. Moreover, it is controversial its role in preventing the postsurgical recurrences of implants, which has been demonstrated in short-term studies for ovarian endometriomas [5]. Differently, hormonal therapies used to treat endometriosis have no role in improving endometriosis-related infertility [6]. The choice of most appropriate therapy is based on intensity of pain, age, desire to conceive, cost, route of administration and impact of the endometriosis on work capacity, sexual function and quality of life (QoL) of each patient [7]. Traditionally combined oral contraceptive (COC) pills have been the first-line treatment for patients with endometriosis, but currently progestins are increasingly and successfully employed as monotherapy, being efficacious and well tolerated $[8,9,10]$. This review aims to summarize the pharmacokinetic $(\mathrm{PK})$ and the clinical efficacy of progestins available for the medical treatment of endometriosis.

A literature search was performed to find all the published studies evaluating PK and clinical efficacy of progestins for the treatment of endometriosis from inception until December 2017. The 
following electronic databases were used: Medline, PubMed, Embase, Science Citation Index via Web of Science, and the Cochrane Library. The following search terms were used: 'endometriosis' alone or in combination with 'progestin', 'medical therapy', 'pregnanes', 'estranes', 'gonanes' 'norethindrone', 'cyproterone', 'desogestrel,'etonogestrel' 'medroxyprogesterone', 'dienogest' 'levonorgestrel-intrauterine device'. All pertinent articles were carefully evaluated and their reference lists were examined in order to identify other manuscripts that could be included in the present drug evaluation.

\subsection{Medical therapy of endometriosis}

Circulating estrogens stimulate the growth of endometriotic implants. Furthermore, it known that estradiol $\left(\mathrm{E}_{2}\right)$ is produced locally by the overexpression of aromatase in the endometriotic implants of all phenotypes of endometriosis $[11,12,13]$. Moreover, also the presence of estrogen and progesterone receptors has been well documented in the three types of endometriosis [14], including DIE [15]. In addition, endometriotic cells produce several prostaglandins that are involved in the inflammatory state, pelvic pain and neo-angiogenesis of implants [16]. The currently available medical therapies for endometriosis primarily exert their action by suppressing ovulation and inducing a relatively hypoestrogenic state. Hormonal therapies, particularly progestins and COCs, have been repeatedly demonstrated to be safe, well tolerated and effective in clinical trials, and currently they represent the first-line medical treatment for women affected by this disease $[17,18]$. Laparoscopic confirmation of the diagnosis of endometriosis may be advisable prior to administering second-line hormonal treatments, such as gonadotropinreleasing hormone agonists (GnRH-a), which induce suppression of the hypothalamic-pituitaryovary axis [19]. If all these treatments are ineffective, experimental therapies, such aromatase inhibitors, may be considered [20]. 


\subsection{Progestins}

Progestogens acts on endometriotic implants exerting systemic and local effect, so that they aim to induce anovulation and hypoestrogenism causing decidualization and acyclicity of both normal and ectopic endometrium. Firstly, on hypothalamus, they reduce the frequency and increase the amplitude of gonadotropin-releasing hormone $(\mathrm{GnRH})$ pulsatile release, thus leading to a reduction in the secretion of follicle stimulating hormone (FSH) and luteinizing hormone (LH). Therefore, the continuous use of progestogens causes suppression of ovarian steroidogenesis with anovulation decreasing serum levels of endogenous ovarian steroids. Moreover, they can locally inhibit inflammatory pathways and response, and provoke apoptosis of endometriotic cells [21]. In particular, it has been demonstrated that they can reduce interleukin (IL)-6, IL-8, and monocyte chemotactic protein (MCP)-1 secretions of endometriotic stromal cells, and cellular proliferation stimulated by tumor necrosis factor- $\alpha(\mathrm{TNF}-\alpha)[22,23]$. Furthermore, they reduce oxidative stress, inhibits angiogenesis as well as suppress expression of matrix metalloproteinases, which may contribute to the development and to the growth of endometriotic lesions (Figure 1) [12, 24]. All these direct effects and the concomitant hypoestrogenic environment associated with hyperprogestogenic systemic status may be responsible for the decidual transformation and consequent atrophy of the normal endometrium and ectopic implants [25].

Progestins, synthetic progestogens, are a chemically various group of compounds with a multiplicity of actions on progesterone receptor as well as estrogen, androgen, mineralocorticoid, glucocorticoid and other receptors. These compounds can be divided in three classes (Figure 2): progesterone derivatives (pregnanes), testosterone derivatives (estranes and gonanes) and spironolactone derivatives. A great variety of progestins, available in different and multiple formulations (Table 1), have been employed in the management of endometriosis in association with estrogens or alone $[17,26]$. However, only progestins belonging to progesterone and testosterone derivatives have been used as monotherapy; while no spironolactone derivate has been tested in this setting. 
The drugs have good tolerability profile. The main progestin-related adverse effects (AEs) experienced by patients are spotting and breakthrough bleeding, depression, breast tenderness and fluid retention. These AEs are also the major cause of discontinuation of treatment in these patients [27].

Currently, among the progestins, only depot medroxyprogesterone acetate (DMPA) and norethindrone acetate (NETA) as monotherapy are approved by the Food and Drug Administration (FDA) for the treatment of endometriosis.

\subsection{Norethindrone acetate}

NETA (17-hydroxy-19-nor-17 $\alpha$-pregn-4-en-20-yn-3-one acetate) is a synthetic, orally active progestin, derivative of 19-nor-testosterone (estrane, testosterone derivate). It has also weak estrogenic and androgenic properties [28].

\subsubsection{Pharmacokinetic}

After oral administration, NETA (5 mg) is completely and rapidly deacetylated to norethindrone (NET) [29], which generally achieves maximum plasma concentration $\left(\mathrm{C}_{\max }\right)$ within 2 hours [30]. Its volume of distribution $\left(\mathrm{V}_{\mathrm{D}}\right)$ is about $4 \mathrm{~L} / \mathrm{kg}$, and it is $61 \%$ bound to serum albumin and $38 \%$ to sex hormone-binding globulin (SHBG). NET undergoes extensive hepatic biotransformation, primarily via reduction, followed by sulfate and glucuronide conjugation [31]. A small extent $(0.20-0.33 \%)$ is converted by hepatic aromatase to ethinylestradiol (EE) [32]. The majority of plasmatic NET metabolites are sulfates, whereas glucuronides account for most of the urinary metabolites. NET mean total clearance $(\mathrm{Cl})$ is approximately $0.4 \mathrm{~L} / \mathrm{hr} / \mathrm{kg}$, and its metabolites are excreted in both urine and feces. Its terminal elimination half-life $\left(t_{1 / 2}\right)$ after a single oral dose is approximately 9 hours [31].

\subsubsection{Clinical efficacy and safety}


NETA is one of the most studied progestin for the treatment of endometriosis. In a randomized controlled trial (RTC), Vercellini et al. compared NETA (2.5 mg/day) with a COC regimen (EE $0.01 \mathrm{mg}+$ cyproterone acetate $[\mathrm{CPA}] 3 \mathrm{mg})$. The regimens were administered to 90 patients with symptomatic rectovaginal endometriosis. After 12 months, $73 \%$ of women in the NETA group were satisfied or very satisfied with treatment compared to $62 \%$ in the COC group $(p=0.37)$. Both treatments were equally effective in controlling pain symptoms and in reducing the size of the lesions assessed by TVS. Only five of the 45 women (9\%) receiving NETA withdrew because of adverse effects (AEs) or persistent pain. The most frequently reported AEs in the NETA group were weight gain (27\%) and decreased libido (9\%) [33].

In a patient-preference parallel cohort study, continuous NETA $(2.5 \mathrm{mg} /$ day $)$ was compared to surgery for the treatment of 154 patients with endometriosis-associated deep dyspareunia. In the surgery group (51 women), there was a marked improvement of dyspareunia, followed by partial recurrence of pain. In the NETA group (103 patients), pain relief was more gradual but progressive throughout the whole study period. Moreover, at the end of 12 months of follow-up, patients treated with NETA had a greater increase in intercourse frequency per month and had higher satisfaction (59\% versus $43 \%$ ). At 1 -year follow-up, NETA had better outcomes than surgery in patients without DIE implants. Moreover, among patients with rectovaginal nodules, NETA showed comparable efficacy [34].

Ferrero et al. investigated the efficacy of NETA for the treatment of pain and gastrointestinal symptoms in 40 women with colorectal endometriosis. This drug improved the intensity of deep dyspareunia, dyschezia and chronic pelvic pain, causing also the disappearance of symptoms related to the menstrual cycle. Moreover, it improved the severity of diarrhea, intestinal cramping and passage of mucus of these patients. On the other hand, its administration did not have a significant effect on constipation, abdominal bloating and feeling of incomplete evacuation after bowel movements. $32(80 \%)$ women completed the study protocol, and the most common causes for interruption of treatment were worsening of constipation $(n=3)$ and breakthrough bleeding $(n=2)$. 
The presence of intestinal endometriosis was confirmed in all patients who underwent surgery after the end of the treatment $(n=13)[35]$.

A prospective, non-randomized, open-label study including 40 patients compared the changes in the volume of ovarian endometriotic cysts during 6-month treatment with NETA alone or combined with letrozole. Both treatments significantly decreased the volume of endometriomas; however, the decrease in the volume of endometriomas was higher in patients receiving the double-drug regimen than in those receiving NETA alone. The improvement in pain symptoms was similar in the two study groups. After the discontinuation of treatment, the volume of endometriotic cysts progressively increased and after 6 months it was similar to baseline in both study groups [36]. In a long-term retrospective cohort study, 103 women with pain symptoms caused by rectovaginal endometriosis received NETA ( $2.5 \mathrm{mg}$ /day up to $5 \mathrm{mg} /$ day) for a 5 -year therapy. Overall, $68.8 \%$ $(42 / 61)$ of the women who completed the study were satisfied or very satisfied of NETA. Intensity of chronic pelvic pain and deep dyspareunia significantly decreased during treatment $(\mathrm{p}<.001$ versus baseline at 1 - and 5-year). Dyschezia improved after 1 -year compared to baseline $(\mathrm{p}=0.008)$ but it remained stable between first and second year $(\mathrm{p}=.409)$. Regarding size of implants, a reduction was observed at RMI in 55.9\% (33/59) of women whereas a volumetric increase was observed in $11.9 \%$ of them (7/59) [37].

Recently, a patient preference prospective study demonstrated that NETA ( $2.5 \mathrm{mg} /$ day $)$ and a 91day extended-cycle COC (LNG plus EE $150 / 30 \mu \mathrm{g}$ for 84 days and EE $10 \mu \mathrm{g}$ for 7 days) have similar efficacy in treating pain symptoms related to endometriosis [38]. However, the extendedcycle OC caused more unscheduled bleeding than NETA.

Regarding safety-profile of NETA by evaluating the largest series available, among 271 patients the most common AEs experienced were weight gain $(n=78,28.8 \%)$, breakthrough bleeding $(n=45$, $16.6 \%)$ and decreased libido $(n=34,12.5 \%)[6,37,39]$.

\subsection{Cyproterone acetate}


Cyproterone acetate (CPA, 6-Chloro-17 $\alpha$-hydroxy-1 $\alpha, 2 \alpha$-methylenepregna-4,6-diene-3,20-dione acetate) is a synthetic steroid with antiandrogenic and progestinic proprieties (gonane, testosterone derivate) [40].

\subsubsection{Pharmacokinetic}

An intra-individual comparison study investigated the PK of CPA in six healthy women. Following oral administration of $\mathrm{CPA}-{ }^{14} \mathrm{C}(2 \mathrm{mg})$, administered together with $\mathrm{EE}(50 \mathrm{pg})$, the maximum radioactivity in the total plasma volume was $2.0 \%$ of the dose. After 24 hours from its administration, $0.63 \%$ of the dose was detected in plasma, and the mean CPA- ${ }^{14} \mathrm{C}$ AUC was $26.7 \%$. Disposition phase 1 was recognizable in the period between the $C_{\max }$ and $12-16$ hours after administration and passed with a $t_{1 / 2}$ of $3-4$ hours. In the period from 24 hours to day 3 , the plasma concentration fell more slowly with a $t_{1 / 2}$ of approximately 2 days [41]. In terms of plasma protein binding, CPA does not bind to SHBG or transcortin and is instead bound exclusively to albumin (93\%) [42]. Thus, the terminal $t_{1 / 2}$ of the total activity in plasma was determined as 1.7 days. CPA is almost completely metabolized via the cytochrome P450 isoenzyme CYP3A4, and its main metabolite is $15 \beta-\mathrm{OH}-\mathrm{CPA}$. In the study, its quotient of the elimination urine: faces was 0.5 , with mean balances of $88 \%$ of the dose [41].

\subsubsection{Clinical efficacy and safety}

The use of CPA as monotherapy for the treatment of endometriosis has been investigated only in two studies. A pilot study by Moran et al. on seven women with surgically confirmed endometriosis evaluated the effectiveness of 6-month cyclical CPA (10 mg/day for 20 days, followed by 10 days without medication). The regimen improved dysmenorrhea in all the patients. At second-look laparoscopy, five patients (71\%) had minimal endometriosis and two patients (29\%) had no evidence of the disease [43].

In a RCT, Vercellini et al. compared the efficacy and safety of low-dose CPA (12.5 mg/day) with a COC (EE $0.02 \mathrm{mg}+$ desogestrel, DSG, $0.15 \mathrm{mg}$ ) in 90 women with recurrent moderate or severe endometriosis-related pelvic pain persisting after conservative surgery. At 6 months, $73 \%$ of 
women who received CPA were satisfied or very satisfied (versus $67 \%$ of those receiving the COC; $\mathrm{p}=.65)$. Dysmenorrhea, deep dyspareunia, and non-menstrual pelvic pain scores were substantially reduced and significant improvements in QoL, psychiatric profile, and sexual satisfaction were observed in both treatment groups. Amenorrhea was reached in approximately $66 \%$ of women who received CPA and in about $50 \%$ of those who received COC. The withdrawal rate was similar in both groups (9 and 6 patients, respectively) [44].

Regarding safety profile of CPA as monotherapy for endometriosis, in the study by Vercellini et al. the main AEs experienced were bloating or swelling ( $n=14,32 \%)$, spotting $(n=12,28 \%)$ and weight gain $(\mathrm{n}=8,19 \%)$. The mean weight gain was $2.4 \mathrm{~kg}$ (versus $2.2 \mathrm{~kg}$ for COC) whereas there were no significant changes in serum lipid profiles. Moreover, the main AEs that caused CPA discontinuation were bloating $(\mathrm{n}=1)$, decreased libido $(\mathrm{n}=1)$, depression $(\mathrm{n}=1)$, and headache $(\mathrm{n}=1)$ [44].

\subsection{Desogestrel}

DSG (3-Deketo-11-methylene-17 $\alpha$-ethynyl-18-methyl-19-nortestosterone) is a third-generation 19nortestosterone derivative progestin (gonane, testosterone derivate) [45]. It is commonly used in various formulations for hormonal contraception including combinations with EE, progestin-only pill and subdermal implants [46].

\subsubsection{Pharmacokinetic}

After oral administration, the DNG bioavailability is about $76 \%$. It is rapidly absorbed and converted to 3-keto DSG (or etonogestrel, ETN) [47] by hydroxylation and subsequent oxidation. The conversion occurs fairly rapidly in vivo, with prevalent hepatic metabolism by cytochrome (CYP) P450 and a moderate contribution of the intestinal mucosa [48]. The bio-activation of DSG to ETN has a wide variation between patients, ranging from 40 to $113 \%$ of the dose [49]. ETN is responsible for the pharmacological effect, exerting much stronger progestogen activity than the 
parent compound. During multiple oral administration of DSG $(75 \mu \mathrm{g})$, the $\mathrm{C}_{\max }$ of ETN is approximately $640 \mathrm{pg} / \mathrm{ml}$ and it is achieved within $2 \mathrm{~h}$. Its steady state is reached after 4 days. ETN is largely bound to serum albumin (58\%) and SHBG (38\%), and 3.5\% remains unbound and bioactive. ETN is subsequently metabolized to polar derivatives in the liver. The ETN $\mathrm{t}_{1 / 2}$ is about $30 \mathrm{~h}$, with no difference between single and multiple oral doses [50]; the drug is predominantly ( $\sim 60 \%)$ excreted via urine, and only about $35 \%$ is excreted via feces [51].

\subsubsection{Clinical efficacy and safety}

In the first study reported, continuous oral DSG (75 $\mu \mathrm{g}$ /day) was compared to COC (EE $20 \mu \mathrm{g}+$ DSG $150 \mu \mathrm{g}$ /day) for the treatment of 40 patients with stage I-II endometriosis. At 6-months of follow-up, pelvic pain improved without difference between the two study arms. Moreover, breakthrough bleeding (20\%) was the main AE reported in the DSG group [52].

In an open-label prospective trial, the combinatory regimen of oral DSG and an aromatase inhibitor (letrozole, $2.5 \mathrm{mg} /$ day) was studied in the 6-month treatment of 12 patients with persistent endometriosis-related (stage IV) pelvic pain, not responding to previous surgical and medical therapies. None of the patients completed the treatment course because of the development of functional ovarian cysts; the median length of treatment of 84 days (range 56-112). This AE should be ascribed to the aromatase inhibitor. In fact, this drug blocks the conversion of androgens to estrogens in ovarian granulosa cells, with a consequent reduction of the negative feedback at the pituitary-hypothalamus level, and therefore, increase of serum FSH levels that promoted the ovarian follicles growth. Although the authors chose to combine letrozole with DSG to inhibit effectively ovulation, the progestin did not prevent the development of functional ovarian cysts. During the treatment period, all the patients had significant improvements in dyspareunia and chronic pelvic pain. The main AEs in both groups were abnormal bleeding (75\%), weight gain $(50 \%)$ and abdominal bloating (42\%) [53].

In 2014, a patient preference trial compared the contraceptive vaginal ring (EE $15 \mu \mathrm{g}+\mathrm{ENG} 120$ $\mu \mathrm{g})$, administered cyclically, with oral DSG (75 $\mu \mathrm{g} /$ day) for the treatment of women with 
symptomatic rectovaginal endometriosis. In this trial, 60 women received DSG and 83 women the vaginal ring. At the end of the 12-months of treatment, the rate of satisfied women was higher in the DSG group (61.7\% versus $36.1 \%)$. There was no difference in the withdrawal rate between the two study groups. Moreover, the two treatments caused a similar disease volume size reduction. Interestingly, gastrointestinal symptoms, chronic pelvic pain, and deep dyspareunia improved more in patients receiving DSG [54].

In another patient preference study, oral DSG (75 $\mu \mathrm{g} /$ day) and cyclic COC (EE $20 \mu \mathrm{g}+\mathrm{DSG} 150$

$\mu \mathrm{g})$ were administered to 74 women with symptomatic rectovaginal implants and migraine without aura [55], which has been demonstrated to be often associated to endometriosis [56]. Both treatments were equally effective in decreasing endometriosis-related pain. After 6 months of treatment, the withdrawal rate was higher in the COC group (24.4\% versus $11.3 \%)$, but the number of days with bleeding was higher in the DSG group (5.1 versus 3.2 days). The satisfaction rate was higher for patients receiving DSG (61.2\% versus $37.8 \%)$, which showed also a significant improvement in QoL. In addition, the severity and number of migraine attacks were significantly different between baseline and the end of treatment in the DSG group $(\mathrm{P}<.001)$ but not in COC group ( $\mathrm{P}=.078)$. Regarding available safety data on DSG as monotherapy for endometriosis, this latter trial demonstrated that among 31 patients, the most common AEs were acne (3.2\%), nausea $(3.2 \%)$, breast pain $(6.4 \%$ in the POP group) and weight gain $(6.4 \%)$ [55].

\subsection{Etonogestrel-subdermal implant}

ENG (11-Methylene-17 $\alpha$-ethynyl-18-methyl-19-nortestosterone) is the derivative active form of DSG (gonane, testosterone derivate). It is available as single-rod progestin contraceptive subdermally placed in the inner upper arm for long-acting (three years) reversible contraception in women. The implant consists of a $40 \mathrm{~mm}$ by $2 \mathrm{~mm}$ semi-rigid plastic (ethylene vinyl acetate) rod containing ENG at dose of $68 \mathrm{mg}$ [57].

\subsubsection{Pharmacokinetic}


ENG is initially slowly released from the subdermal implant at $60-70 \mathrm{mcg} / \mathrm{day}$, decreasing to $35-45$ $\mathrm{mcg} / \mathrm{day}$ at the end of the first year, to $30-40 \mathrm{mcg} / \mathrm{day}$ at the end of the second year, and then to $25-$ $30 \mathrm{mcg} /$ day at the end of the third year. After 4 days from the application of the implant, ENG achieves the $\mathrm{C}_{\max }$ of $813 \mathrm{pg} / \mathrm{ml}$. After 4-6 months, it reaches the steady state of $200 \mathrm{pg} / \mathrm{ml}$ that remains sufficient to prevent ovulation for three years. It has been demonstrated that the ENG plasmatic levels are $40 \%$ higher in women weighing $<50 \mathrm{~kg}$ [58]. This drug is approximately $32 \%$ bound to SHBG. The total body $\mathrm{Cl}$ of ENG is around $7.5 \mathrm{~L} / \mathrm{h}$, and it remains constant during the time. Thus, it can be assumed that there is no accumulation of steroid drug and that the decreased serum concentrations are caused only by a slight lowering in the release rate over time [59]. After implant removal, plasmatic ENG is not detectable within 1 week [58].

\subsubsection{Clinical efficacy and safety}

Few data are available on the use of the ENG-subdermal implant for the treatment of women with endometriosis (Table 2). In an uncontrolled open clinical trial, the ENG-subdermal implant efficacy was evaluated in 50 symptomatic women with surgically confirmed endometriosis. The authors reported an improvement of pain levels and a high satisfaction rate (80\%). After a short follow-up (12 weeks), women had spotting (26\%) and intermestrual bleeding (4\%) [60].

In a RTC, Walch et al. compared the efficacy of ENG-subdermal implant ( $\mathrm{n}=21$ patients) to DMPA-SC $(n=20)$ for the treatment of pain related to endometriosis. After 6-months of treatment, the mean reduction in pain was $68 \%$ in the ENG subdermal implant group and $53 \%$ in the DMPASC group. The overall degree of satisfied plus very satisfied subjects was almost identical in both groups (57\% in the ENG-subdermal implant group versus 58\% in the DMPA group), and, at 1-year follow-up, also the improvement in pain intensity was equivalent [61].

Safety data from the trial by Walch et al demonstrated that the most common AEs in patients receiving ENG-subdermal implant were breast tenderness (24\%) and libido decrease (24\%). Moreover, there was a lower withdrawal rate in the ENG group $(n=4,19 \%)$ compared to the DMPA-SC group $(n=7,35 \%)$. The main cause of ENG-discontinuation was unbearable bleeding 
irregularities $(\mathrm{n}=2,50 \%)[61]$.

The effect of ENG-subdermal implant on bone mineral density (BMD) is controversial: in a prospective study, in which it was compared to non-hormone-medicated intrauterine device (IUD), similar changes in BMD were demonstrated from baseline to the end of treatment. In particular, the clinically significant mean decrease of $z$-score -1 was not nearly reached at all the anatomical sites of the body measured in both groups [62]. In contrast, another group reported a significantly decrease of $-5.90 \%(\mathrm{P}<0.001)$ on forearm BMD after 18 months from ENG-subdermal implant insertion [63].

\subsection{Medroxyprogesterone acetate}

Medroxyprogesterone acetate (MPA, 6 $\alpha$-Methyl-17 $\alpha$-hydroxyprogesterone) is a synthetic derivative of 17-hydroxyprogesterone (pregnane, progesterone derivative). MPA is available as oral formulation or depot formulation, which can be administered intramuscularly (DMPA-M) [64] and subcutaneously (DMPA-SC) every 3 months [65]. This progestin has also anti-androgenic and strong anti-glucocorticoid effect (thirty times higher than either DNG or NETA) [66].

\subsubsection{Pharmacokinetic}

MPA (10-15 mg) is rapidly absorbed from the gastrointestinal tract, and its $\mathrm{C}_{\max }$ is obtained within 2-4 hours after oral administration. MPA is approximately $90 \%$ bound to serum proteins, with the exception of SHBG. MPA is extensively hydroxylated and conjugated in the liver via CYP3A4, and it is subsequently eliminated in the urine. Administered in multiple dose (10-15 mg three-times a day for 90 days), such as suggested for the treatment of endometriosis, its reported $t_{1 / 2}$ is more than 30 hours [67].

Following a single dose of DMPA-M (150 mg IM), MPA concentration increases for approximately 3 weeks to reach a $\mathrm{C}_{\max }$ of $1-7 \mathrm{ng} / \mathrm{mL}$. The concentrations of MPA decrease exponentially until becoming undetectable $(<100 \mathrm{pg} / \mathrm{mL})$ between 120 to 200 days following injection [68]. 
DMPA-SC releases constantly MPA, reaching a $\mathrm{C}_{\max }$ of $0.953 \mathrm{ng} / \mathrm{mL}$ after $2-14$ days from the administration. Overall, mean MPA levels at days 91,104 and 120 are $0.427,0.367$ and 0.327 $\mathrm{ng} / \mathrm{mL}$, respectively. MPA mean $\mathrm{AUC}_{0-91}$ is $45.1 \mathrm{ng} \cdot \mathrm{day} / \mathrm{mL}$. It has been shown that MPA concentrations remains above $0.2 \mathrm{ng} / \mathrm{mL}$ for at least 91 days [69].

\subsubsection{Clinical efficacy and safety}

Since the 1970s, retrospective studies have suggested that oral MPA (30-50 mg/day) is effective in treating pain symptoms in women with endometriosis $[70,71,72]$. In two RCTs, Telimaa et al. demonstrated that the administration of MPA (100 mg/day) for 6 months is as effective as danazol in the treatment of pain both after diagnostic laparoscopy [73] and after surgical excision of endometriosis [74]. One prospective double-blind RCT, involving 48 women with surgical diagnosis of endometriosis, compared MPA (45 mg/day) with naferelin (400 $\mu \mathrm{g}$ intranasal) for treating pain. Patients were treated for 6 months and followed for 1 year. There was a significant reduction in the severity of pain symptoms during the study, without any significant difference between the study groups [75]. These findings are in contrast to a prospective, double-blind RCT involving 100 infertile women (only $25 \%$ of them had mild-severe pelvic pain) with a surgical diagnosis of endometriosis, which compared the efficacy of 3-month administration of MPA (50 $\mathrm{mg}$ /day) with placebo [76].

From data extracted and analyzed from RTCs, a Cochrane review reported that MPA (100 mg daily) appears more effective in reducing all symptoms up to 12 months of follow-up (MD -0.70, 95\% CI -8.61 to $-5.39 ; \mathrm{P}<0.00001)$ compared with placebo. Moreover, patients receiving MPA had more cases of acne and edema [77].

DMPA has been investigated in few clinical trials for the treatment of women with endometriosis (Table 2). In a RTC (80 women), Vercellini et al. compared DMPA-M (150 mg/3 months) to cyclic COC plus oral danazol (50 mg/day) for 1 year to treat endometriosis-related pelvic pain. 40 patients were allocated in each study arm. At the end of treatment, $72.5 \%$ of the women in the DMPA-M arm were satisfied or very satisfied compared with $57.5 \%$ in COC plus danazol arm $(p=0.24)$. A 
significant decrease in all symptoms scores was reported in both study arms without significant differences. The main AEs in the DMPA-M group were spotting (26\%), bloating (25\%) and weight gain $(21 \%)$. In addition, the median time to return of regular menstrual flow in women who received DMPA-M was 7 months. In both arms, there was a significant reduction in high-density lipoprotein cholesterol [78].

A RCT compared a 3-years regimen of DMPA-M (150 mg/3 months) with the levonogestrelreleasing intrauterine system (LNG-IUD) in 30 patients after conservative surgery for endometriosis. Both treatments were effective in the management of pain symptoms, and the only domains where no amelioration was observed were dyspareunia and urinary/bowel symptoms. At TVS, no recurrence of lesions was detected in both groups. The dropout rate was higher in the DMPA-M group (53\% versus 13\%), and the two most common causes of discontinuation among the eight patients that interrupted DMPA-M were prolonged vaginal spotting $(n=3,37.3 \%)$ and significant bone loss over the lumbar spine $(n=2,25 \%)$ [79].

In two large RTCs, Crosignani et al. and Schalff et al. compared DMPA-SC (104 mg/0.65 ml) with leuprolide acetate (given every 3 months for 6 months). At 12-months of follow-up, DMPA-SC was statistically equivalent to GnRH-a in reducing pain symptoms. Moreover, significant improvements in QoL occurred in both treatment groups [80, 81]. Interestingly, in the study by Crosignani et al. patients who received DMPA-SC reported a significant amelioration in their sexual relationship after 6 months of treatment [80].

One of major sources of concerns regarding the continuous DMPA use is the breakthrough bleeding, the primary reason for its discontinuation among women using it for contraception [82]. Moreover, pooled analysis from three Phase III contraceptive trials demonstrated that the therapy with DMPA (SC and M) causes gained weight $[83,84]$. A further concern on DMPA use is the loss of BMD, which may increase the risk of fracture [85]. For this reason, in 2004 the FDA published a 'black box warning', suggesting physicians its administration only if the other methods were unsuitable or unacceptable, limiting the maximum use to 2 years [86]. 
Regarding data on safety of DMPA ( $\mathrm{SC}$ and $\mathrm{M}$ ) for the treatment of endometriosis from evaluable trials, among 282 patients, $49.3 \%$ had a drug-related AE. The most common AEs were breakthrough bleeding $(n=39,12.1 \%)$, nausea $(n=29,9.0 \%)$, headache $(n=26,8.0 \%)$ and bloating $(\mathrm{n}=25,7.8 \%)$. Specifically for DMPA-SC, in the studies by Crosignani et al. and Schalff et al., after 6 months of treatment, the patients receiving the depot progestin group showed significantly less BMD loss than those treated with leuprolide; anyway, BMD returned to pretreatment levels at 12 months' follow-up. Moreover, when compared to GnRH-a, DMPA-SC caused less hypoestrogenism-related symptoms, such as headache (3.3-7.7\% versus $6.3-10.4 \%)$ and hot flushes (2.3-5.9\% versus $11.1-16.8 \%)$, but more irregular bleeding, varying from light spotting to uterine hemorrhage (5.4-12.5\% versus $0.7 \%$ ). However, in these two studies the discontinuation rate secondary to AEs was 2-5.4\% in the DMPA-SC group and $1.4-6.7 \%$ in the leuprolide group [80, 81].

\subsection{Dienogest}

Dienogest (DNG, 17 $\alpha$-Cyanomethyl- $\delta 9-19$-nortestosterone) is a fourth-generation selective progestin (estrane, testosterone derivate). It has minimal androgenic, estrogenic, glucocorticoid or mineralocorticoid activity [87].

\subsubsection{Pharmacokinetic}

After a single dose, DNG $(2 \mathrm{mg})$ has high bioavailability $(<90 \%)[88]$, reaching a mean $\mathrm{C}_{\max }$ of $51.7 \mathrm{ng} / \mathrm{mL}$ within $1.0 \mathrm{~h}$ (range of $0.7-4 \mathrm{~h}$ ). Its mean $\mathrm{AUC}_{0-24 \mathrm{~h}}$ is $503 \mathrm{ng} \cdot \mathrm{h} / \mathrm{mL} .90 \%$ of DNG binds to albumin, whereas only $10 \%$ is present in plasma in the free form. The $\mathrm{DNG} \mathrm{t}_{1 / 2}$ is $10.6 \mathrm{~h}$ with a mean $\mathrm{Cl}$ of $3.28 \mathrm{~L} / \mathrm{h}$. DNG has no relevant interaction with various hepatic binding globulins such as SHBG and corticosteroidbinding globuline (CBG) [66]. CYP 3A4 is the most widely used enzyme in the metabolic pathway of DNG. The excretion of DNG takes place mainly through the urine after glucuronide and sulfate conjugation and most of the metabolites are eliminated during 
the first 24 hours [89]. After once daily multiple doses, the mean $\mathrm{C}_{\max }$ and $\mathrm{AUC}_{0-24 \mathrm{~h}}$ of $\mathrm{DNG}$ slightly increase, resulting after 14 days in $56.6 \mathrm{ng} / \mathrm{mL}$ and $613 \mathrm{ng} \cdot \mathrm{h} / \mathrm{mL}$, respectively. Moreover, in case of multiple administrations, its mean $\mathrm{t}_{1 / 2}$ and total body $\mathrm{Cl}$ are approximately $11.0 \mathrm{~h}$ and 3.32 $\mathrm{L} / \mathrm{h}$, respectively [90].

\subsubsection{Clinical efficacy and safety}

Several RTCs have investigated the use of DNG for the treatment of endometriosis (Table 3) [91]. A systematic review showed that DNG (2 mg/day) is superior to placebo in reducing pelvic pain (27.4 versus $15.1 \mathrm{~mm}, \mathrm{P}<.0001)$ and as effective as $\mathrm{GnRH}-\mathrm{a}$ in controlling symptoms associated with endometriosis. Moreover, DNG is effective in reducing endometriotic lesions $(11.4 \pm 1.71-3.6$ $\pm 0.95, \mathrm{P}<.001)[92]$. Concerning the use of DNG as maintenance therapy after GnRH-a to treat pelvic pain associated with endometriosis, Kitawaki et al., in a prospective nonrandomized clinical trial, showed that long-term administration of DNG following GnRH-a therapy prolongs the relief of pelvic pain while reducing the amount of irregular uterine bleeding [93].

In a 6-months double-blind multicenter RTC, DNG ( $2 \mathrm{mg} /$ day $)$ efficacy and safety were evaluated in 255 Chinese patients with laparoscopically diagnosed endometriosis. At baseline, they had an endometriosis-associated pelvic pain (EAPP) score $\geq 30 \mathrm{~mm}$ on a $0-100 \mathrm{~mm}$ visual analog scale (VAS). After the end of treatment, DNG obtained a higher mean reduction in EAPP score than placebo (-24.54 mm; 95\% CI -29.93 to $-19.15 ; \mathrm{p}<0.0001)$. Moreover, DNG was well tolerated, although the incidence of drug-related AEs was higher to that of patients receiving placebo $(29.4 \%$ vs $10.1 \%$ ), with intensity of AEs mild-to-moderate in most women. Anyway, the AE-related discontinuation rate for both groups was comparable (1.6\% vs $0.8 \%)$ [94].

Morotti et al. investigated the DNG efficacy for the treatment of women with rectovaginal endometriosis who had persisting pain symptoms during the administration of NETA. In this 24weeks open-label prospective study, the authors evaluated the satisfaction of 25 patients after 6 months of DNG treatment. DNG obtained better results than NETA both in terms of pain relief and in terms of QoL improvement, which were evaluated with the Endometriosis Health Profile-30 
(EHP-30) and Female Sexual Function Index (FSFI) questionnaires. Moreover, the endometriotic nodules volume did not significantly change during treatment. More common AEs in the DNG group included headache $(16.0 \%)$, nausea $(8.0 \%)$, breast tenderness $(4.0 \%)$ [95].

DNG has also been used for the conservative treatment of bladder endometriosis [96]. In recent pilot study including six women with bladder endometriotic lesions, the administration of DNG (2 $\mathrm{mg}$ /day) for 12 months improved pain symptoms. Furthermore, urinary symptoms disappeared in all the patients and there was a significant size decrease of bladder nodules at TVS after 3 and 12 months of treatment [97]. In a prospective study, Leonardo-Pinto et al. evaluated the effectiveness of DNG for the treatment of 30 women with DIE. After 12 months, they achieved a significant improvement in dysmenorrhea $(p<.0001)$, pelvic pain $(p=.0007)$, dyspareunia $(p=.0093)$, and intestinal pain $(\mathrm{p}<0.0001)$, with pain score at VAS reduced at least equal or to less than three for all endometriosis-related symptoms. However, there was not a significant reduction in the volume of the lesions assessed by TVS [98].

Vercellini et al., through a before-after study design, compared NETA and DNG for the treatment of women with endometriosis. Both drugs caused pain relief and improvement of psychological status, sexual functioning, and health-related QoL of the patients. After 6 months, the proportion of satisfied plus very satisfied women was almost identical between the two study groups $(71 \%$ in NETA group versus $72 \%$ in DNG group). After DNG implementation, the absolute risk reduction in the occurrence of any AE compared to NETA was $13.9 \%$ Thus, DNG was better tolerated than NETA, but the much higher cost limited its acceptance by the women [99]. Surprisingly, up to now no RCT compared DNG with COCs or other progestins, the first-line therapies most commonly used for the treatment of endometriosis [91].

A recent study has evaluated the safety and tolerability of DNG among patients with endometriosisassociated pain by pooling data from four randomized, controlled, European studies. Overall, 332 women were treated with DNG (2 mg/day) for study periods ranging between 12 weeks and 65 
weeks. The most common drug-related AEs were headache, breast discomfort, depressed mood, and acne, occurring in $9.0 \%, 5.4 \%, 5.1 \%$, and $5.1 \%$ of women, respectively [100]. The effect of DNG on BMD is controversial. In a comparative study, Lee et al. administered DNG ( $2 \mathrm{mg} /$ day) or GnRH-a plus add-back therapy (NETA $0.5 \mathrm{mg}$ /day or $\mathrm{E}_{2} 1 \mathrm{mg} /$ day) for the treatment of endometriosis. The authors reported a decline in BMD at the lumbar spine in both treatment groups ( $-2.3 \%$ for DNG and $-2.5 \%$ for GnRH-a plus add-back) [101]. These results are in line with those reported by Momoeda et al. that showed a significantly decrease $(-1.6 \%)$ of lumbar spine BMD after 24 weeks of treatment with DNG in 135 patients with endometriosis [102]. In contrast, Strowitzki et al. and Lang et al. reported no or minimal changes in BMD $(-0.10 \%$ and $+0.25 \%$ at lumbar spine, respectively) following a 6-month treatment with DNG [94, 103].

\subsection{Levonorgestrel-releasing intrauterine device}

Levonogestrel (LNG, 17 $\alpha$-Ethynyl-18-methyl-19-nortestosterone) is a synthetic second-generation progestin chemically derived from 19-nortestosterone (gonane, testosterone derivate). It is six times more potent than progesterone, but also has strong androgenic properties. Most of the interest for LNG in the treatment of endometriosis is focused on the LNG-releasing intrauterine device (LNGIUD) [104].

\subsubsection{Pharmacokinetic}

LNG-IUD (52 $\mathrm{mg}$ ) releases low doses of LNG directly into the uterine cavity. Its initial release rate is approximately $20 \mu$ /day over the first 3 months (day 0-90), it is reduced to approximately 18 $\mu$ /day after 1 year and then decreases progressively to approximately $10 \mu$ day after 5 years [105]. A stable serum LNG concentration of approximately $150-200 \mathrm{pg} / \mathrm{mL}$ occurs after the first few weeks, following insertion of LNG-IUD [106]. LNG concentrations at 12-, 24- and 60 months have been estimated to be $180 \mathrm{pg} / \mathrm{mL}, 192 \mathrm{pg} / \mathrm{mL}$, and $159 \mathrm{pg} / \mathrm{mL}$, respectively. When released, LNG has a $\mathrm{V}_{\mathrm{D}}$ of approximately $1.8 \mathrm{~L} / \mathrm{kg}$, and it is about $98-99 \%$ bound to serum proteins $(47.5 \%$ to 
SHBG) [66]. The excretion of LNG and its phase I metabolites is primarily as glucuronide conjugates via urine in about $45 \%$ and via feces in about $32 \%$ of total [105].

\subsubsection{Clinical efficacy and safety}

The most important mechanism of action of the LNG-IUD is through its local suppressive action on the endometrium. Amenorrhea develops in approximately $20 \%$ of LNG-IUD users by one year [105]. In patients with endometriosis, the LNG-IUD decreases the expression of glandular and stromal estrogen ( $\alpha$ and $\beta$ ) and progesterone receptors in the ectopic endometrium and, thus, induces glandular atrophy and decidualization of the stroma [107, 108].

A pilot-study including 11 women with symptoms caused by rectovaginal endometriosis demonstrated that the use of the LNG-IUD improved the severity of all pain symptoms, including deep dyspareunia and dyschezia, at 1-year follow-up. Moreover, the LNG-IUD succeeded in decreasing the rectovaginal lesions size, evaluated by transrectal ultrasound and TVS [109]. Several RTCs have investigated the use of LNG-IUD for the treatment of endometriosis (Table 4). Chwalisz et al. compared the efficacy of LNG-IUD and depot GnRH-a (leuprolide $3.75 \mathrm{mg}$ ) in 82 women with endometriosis-related pain over a period of six months. At 6 months of follow-up, both treatments were similarly effective in improving chronic pelvic pain, demonstrating a six-point decrease from baseline in the VAS pain score. At the end of the study, $13 \%(n=5)$ of patients in the LNG-IUD group and the $14 \%(n=6)$ of those in the leuprolide group failed to reach a VAS pain score of less than three. Furthermore, no difference was observed between groups with reference to improvement in QoL [110]. In a meta-analysis including five RCTs, the comparative evaluation of LNG-IUD and GnRH-a demonstrated that both regimens succeed in reducing pain, as well as CA125 serum levels and the American Society of Reproductive Medicine staging scores. Irregular bleeding, simple ovarian cysts and one-sided lower abdominal pain occurred more commonly in patients receiving the LNG-IUD $(\mathrm{P}<.03)$, whereas those receiving GnRH-a experienced more hypo-estrogenic AEs $(\mathrm{P}<.05)[111]$.

The long-term therapy with LNG-IUD has been evaluated in a retrospective study by Lockhat et al., 
in which it resulted efficacious in improving symptoms throughout a 3-year study period [112].

These results are in line with those obtained in a RCT that compared the 36-month use of LNG-IUD with DMPA-M in 30 patients with moderate and severe endometriosis. The mean pain score evaluated at VAS was significantly reduced by the next visit at three months after insertion of LNG-IUS $(\mathrm{P}<.02)$ or starting of DMPA-M injection $(\mathrm{P}<.002)$, and the effect was maintained all through the study period as long as the therapy was continued. Anyway, there was no significant specific change in dyspareunia and urinary and bowel symptoms in both groups of patients [79]. The LNG-IUD has been used for the post-surgical prevention of endometrioma recurrence. In their randomized prospective studies, Tanmahasamut et al. and Wong et al. did not identify any endometrioma recurrence after 12 and 36 months of treatment with LNG-IUD, respectively [79, 113]. In two retrospective studies, the postoperative LNG-IUD use was superior to COCs in preventing endometrioma recurrence $[114,115]$. In contrast, a retrospective study reported a cumulative postoperative endometrioma recurrence rate of $25 \%$ after 5 years of treatment with LNG-IUD [116]. More recently, Kim et al. in a RTC demonstrated equivalent recurrence rate of endometrioma between women allocated in LNG-IUD group (10/40, 25\%) and those in the expectant management group $(15 / 40,37.5 \%)$ at 30-months of follow-up. In both study groups, patients received an initial treatment, after laparoscopic cystectomy, with six cycles of GnRH-a. The number of recurrent endometrioma requiring a second surgery or a hormonal treatment was significantly higher in the expectant management group (8/40, 20\% versus $1 / 40,2.5 \%)$ [117]. Regarding the safety profile of LNG-IUD as post-surgical monotherapy for endometriosis, in the two largest RTC evaluable for drug-related AEs, among 48 patients, the most common were oily skin $(n=20,41.6 \%)$, weight gain $(n=19,39.5 \%)$, breast tenderness $(n=18,37.5 \%)$ and irregular bleeding $(\mathrm{n}=17,35.4 \%)[113,118]$.

\subsection{Conclusion}


Endometriosis, a chronic and recurrent disease, represents a challenge to health-care providers and a burden on the health care system. If COCs have been used for decades as the first-line treatment for endometriosis, progestins are increasingly and successfully employed as monotherapy. In fact, progestins as monotherapy induce decidualization and atrophy of implants and improvement of symptoms of patients with endometriosis, they are relatively well-tolerated and most of them are inexpensive. Further studies are required to compare the efficacy and tolerability of different types of progestins in the treatment of endometriosis.

\subsection{Expert opinion}

Currently, the medical choices for symptomatic endometriosis are based on patient preferences and treatment goals as well as the efficacy and the safety-profile, the desire of contraception, the cost, and the route of administration of the drugs. As endometriosis is a chronic and recurrent disorder, a long-term medical therapy should be well-tolerated, have only limited AEs and be cost-effective [26]. However, hormonal treatments do not eradicate the disease but allow to obtain an effective control of pain symptoms in the $80-90 \%$ of cases. In line with this, recurrence of symptoms is frequent after discontinuation of treatment [119]. While progestins can decrease the volume of endometriomas [36], there is no evidence that the medical therapy can prevent the progression of DIE. Therefore, patients undergoing long-term hormonal treatment for endometriosis-related pain need a follow-up by ultrasonography to timely detect the progression of DIE causing bowel or ureteral stenosis [120].

If COCs have been used for decades as the first-line treatment for symptomatic endometriosis, progestins are increasingly and successfully employed as monotherapy [10]. These drugs are often started empirically without a surgical diagnosis of endometriosis and are particular efficacious in women suffering dysmenorrhea and menstrual-related symptoms.

Progestins cause a lower increase in the thrombotic risk compared with COCs and are better tolerated by patients suffering migraine [121]. A potential disadvantage for the use of progestins in 
women desiring contraception is that only three of them (DSG, ENG-subdermal implant and LNGIUD) are approved as contraceptive. Overall, medical therapy with progestins enables satisfactory long-term pain control in around two-thirds of symptomatic women [2]. The imbalance of ER and PR subtypes or of adhesion molecules imbalance might contribute to the mechanisms involved in the progesterone resistance of patients' population refractory to these hormonal therapies. As no biomarkers for progestin resistance has been proposed, a dynamic monitoring of response to progestins is warranted in order to switch to other options or to discuss in the appropriate time the surgical option [122].

There is lack of data on the specific effects of progestins use on the breast, the mood and cardiovascular system. A French report on contraception with progestins showed that it has never been demonstrated that their use is associated with an increased risk of breast cancer. Moreover, there is no evidence for considering the progestin-only contraception as a risk factor for fractures. Also, the impact of long-term systemic progestins use on BMD is controversial [27].

Data from clinical trials for the treatment of endometriosis suggested that progestins are well tolerated when administered in a long-term treatment. Data from clinical trials suggest that the most frequent AEs reported by the patients are spotting and breakthrough bleeding, weight gain, breast tenderness and depression $[17,18]$. These AEs are also the major cause of discontinuation of treatment.

Currently, randomized, controlled studies support the use of oral progestin-only treatment for controlling pelvic pain associated with endometriosis. Almost none of these trials is double-blinded. A Cochrane review [77] published in 2012 including 13 RCTs evaluated the use of progestins versus placebo, danazol, oral/sub-dermal contraceptives, GnRH-a and other drugs used in the treatment of endometriosis-related pain. When progestins were compared with placebo discordant results emerged: only MPA (100 mg daily) appeared to be more effective in reducing all symptomsrelated to endometriosis compared with placebo. Furthermore, data showed that patients treated with progestins experienced more frequently bleeding or amenorrhea than those who received other 
drugs. A new systematic review with meta-analysis is required in order to include the most recent studies on progestins for treating endometriosis-related pain.

It is well known that progestins can induce decidualization and eventual atrophy of endometriotic implants and that they improve women' pain, but there is a common misconception that all progestins have similar mechanisms of action and PK parameters. Moreover, it is growing the evidence that progestins, in addition to their systemic effect on estrogen production, may also exert an immune-suppressive influence on endometriotic lesions at local disease sites [23] and furthermore that this influence is not uniform for all progestins, depending from the biological activity.

In fact, each one has a distinct biological effect influenced by pharmacodynamics affinity not only for PR, but also for other steroid receptors, such as estrogen, androgen, and glucocorticoid. Moreover, progestins have different route of administration. Most of the available information in literature on the PK of progestins arise from their use as oral contraceptives, often in combination with estrogens. Furthermore, most of the PK studies are focused on their single-dose administration, thus, before achieving the steady-state, which likely correlates with the biological activity of the steroid. In view of their long $\mathrm{t}_{1 / 2}$, steady-state will not be reached before 5-10 days of therapy. At least, there are wide PK variations between patients, probably due to genetic factors and environmental factors. Thus, specific PK data on progestins alone are needed. Overall, knowledge of synthetic progestogens is far to be complete and the situation is further complicated by the multiplicity of biological effects produced by these steroids in human.

The two progestins supported by the largest available evidence in treatment endometriosis are NETA and DNG.

Although FDA licensed oral NETA at $5 \mathrm{mg}$ /day, several studies reported excellent outcomes using only $2.5 \mathrm{mg}$ /day. Its lower dosage increases tolerability, reducing AEs, and limits the negative impact on serum cholesterol values. NETA exerts directly an activity on estrogen receptors $-\alpha$ and $\beta$, and it is a substrate for aromatase, being converted in the liver to a small extent $(0.20-0.33 \%)$ to 
potent EE [32]. For these reasons, unlike most other progestins, NETA has some estrogenic activity, which may be responsible for a positive effect on BMD. NETA is efficacious in the longterm control of endometriosis-related pain [37]; however, being not able to induce a significant regression of implants, it does not represent a definitive curative treatment for this disease. DNG is a new fourth-generation selective progestin. As reported in several clinical trials, DNG showed efficacy and good tolerability at doses of 2-4 mg/ day in continuous administration for 3-24 months in patients with endometriosis. Although DNG seems to be at least equally effective and better tolerated than NETA $[95,99]$, the much higher cost limits its acceptance by patients. A recent review evaluated the PK characteristics of DNG with other progestins derivatives, such as NETA, LNG and gestodene. This comparison showed that DNG is one of few synthetic progestogens that does not bind to SHBG, that has no influence on the PK of testosterone and has no androgenic effects. Moreover, DNG has the highest free-unbounded fraction in the plasma (approximately $10 \%$ ). The high circulating levels of free DNG explain the wide penetration of the molecule in several tissues [66].

An innovative approach to improve the use of progestins in endometriosis is the development of long-acting progestogen systems. In the Cochrane review [77], it has been reported the absence of benefit after depot administration of progestins versus other treatments (low dose COCs or leuprolide acetate). Anyway, only two comparative trials on DMPA were included in this review, and, further studies are needed to draw a definitive conclusion. One of major sources of concerns regarding continuous DMPA use is the decrease of BMD. However, the reversibility of the negative impact of DMPA on BMD toward or to baseline values within 2 years after discontinuation has been demonstrated in several studies $[123,124,125]$ and the data regarding the risk of an eventual fracture are controversial $[126,127,128]$. Furthermore, DMPA is often accompanied by unintentional weight gain, loss of libido, which might adversely affect a woman's QoL and preclude long-term use. Among long-acting progestogen systems, ENG-subdermal implant could be preferable to DMPA in patients with preexisting high BMI and impaired metabolic profiles for its 
lower impact on metabolic profile. Furthermore, the ENG-subdermal implant is particularly useful for patients desiring contraception. The main disadvantage of the depot formulation is the impossibility to interrupt treatment in the event of AEs. In fact, in some patients, the irregular bleeding caused by depot progestins may be prolonged, repeated and difficult to correct. One of the best candidates for the long-term treatment of endometriosis is the LNG-IUD. In comparison with systemic administration, the local release of a drug should theoretically provide a similar or improved efficacy, particularly evident on the local target organ, with reduced systemic AEs. LNG-IUD is particularly suitable for patients with concomitant adenomyosis [129], and who do not want to conceive or wish to postpone pregnancy, whose main symptom is dysmenorrhea, and who do not tolerate progestins administered systemically. Moreover, the LNG-IUD can be inserted at the end of a surgical procedure as a postoperative adjuvant treatment for endometriosis. The results from several RCTs support the use of LNG-IUD with the aim to improve pain. Importantly, the LNG-IUD abolishes or reduces menstruations in the large proportion of women, but it does not inhibit ovulation except for a few months after insertion, raising concerns for the risk of endometrioma recurrence, in line with the theory of endometriomas originating from corpus luteum [130]. Anyway, controversial results of LNG-IUD efficacy on this topic have been reported.

Future double-blinded studies should compare the efficacy and tolerability of different progestins in the long-term treatment of endometriosis-related pain. Population should be select in relation of specific phenotypes of endometriosis. Furthermore, since patients with endometriosis often require to be treated for years, multicentric prospective studies with large sample size should investigate the safety of progestins in the long-term use. 


\section{References}

1. Ferrero S, Arena E, Morando A, et al. Prevalence of newly diagnosed endometriosis in women attending the general practitioner. International journal of gynaecology and obstetrics: the official organ of the International Federation of Gynaecology and Obstetrics. 2010 Sep;110(3):2037. doi: 10.1016/j.ijgo.2010.03.039. PubMed PMID: 20546747.

2. Vercellini P, Vigano P, Somigliana E, et al. Endometriosis: pathogenesis and treatment. Nat Rev Endocrinol. 2014 May;10(5):261-75. doi: 10.1038/nrendo.2013.255. PubMed PMID: 24366116.

3. Vercellini P, De Giorgi O, Pisacreta A, et al. Surgical management of endometriosis. Baillieres Best Pract Res Clin Obstet Gynaecol. 2000 Jun;14(3):501-23. PubMed PMID: 10962639.

4. Vercellini P, Crosignani PG, Abbiati A, et al. The effect of surgery for symptomatic endometriosis: the other side of the story. Human reproduction update. 2009 Mar-Apr;15(2):17788. doi: 10.1093/humupd/dmn062. PubMed PMID: 19136455.

5. Koga K, Takamura M, Fujii T, et al. Prevention of the recurrence of symptom and lesions after conservative surgery for endometriosis. Fertility and sterility. 2015 Oct;104(4):793-801. doi: 10.1016/j.fertnstert.2015.08.026. PubMed PMID: 26354093.

6. Vercellini P, Somigliana E, Consonni D, et al. Surgical versus medical treatment for endometriosis-associated severe deep dyspareunia: I. Effect on pain during intercourse and patient satisfaction. Hum Reprod. 2012 Dec;27(12):3450-9. doi: 10.1093/humrep/des313. PubMed PMID: 22926841.

7. Vercellini P, Somigliana E, Vigano P, et al. Endometriosis: current therapies and new pharmacological developments. Drugs. 2009;69(6):649-75. doi: 10.2165/00003495-20096906000002. PubMed PMID: 19405548.

8. Menakaya U, Infante F, Condous G. Consensus on current management of endometriosis. Hum Reprod. 2013 Nov;28(11):3162-3. doi: 10.1093/humrep/det346. PubMed PMID: 24014606. 9. Dunselman GA, Vermeulen N, Becker C, et al. ESHRE guideline: management of women with endometriosis. Hum Reprod. 2014 Mar;29(3):400-12. doi: 10.1093/humrep/det457. PubMed PMID: 24435778.

10. Casper RF. Progestin-only pills may be a better first-line treatment for endometriosis than combined estrogen-progestin contraceptive pills. Fertility and sterility. 2017;107(3):533-536. doi: 10.1016/j.fertnstert.2017.01.003.

11. Smuc T, Hevir N, Ribic-Pucelj M, et al. Disturbed estrogen and progesterone action in ovarian endometriosis. Mol Cell Endocrinol. 2009 Mar 25;301(1-2):59-64. doi:

10.1016/j.mce.2008.07.020. PubMed PMID: 18762229.

12. Tosti C, Pinzauti S, Santulli P, et al. Pathogenetic Mechanisms of Deep Infiltrating Endometriosis. Reprod Sci. 2015 Sep;22(9):1053-9. doi: 10.1177/1933719115592713. PubMed PMID: 26169038.

13. Greaves E, Temp J, Esnal-Zufiurre A, et al. Estradiol is a critical mediator of macrophagenerve cross talk in peritoneal endometriosis. Am J Pathol. 2015 Aug;185(8):2286-97. doi: 10.1016/j.ajpath.2015.04.012. PubMed PMID: 26073038; PubMed Central PMCID: PMCPMC4530129.

14. Burney RO, Giudice LC. Pathogenesis and pathophysiology of endometriosis. Fertility and sterility. 2012 Sep;98(3):511-9. doi: 10.1016/j.fertnstert.2012.06.029. PubMed PMID: 22819144; PubMed Central PMCID: PMCPMC3836682.

15. Noel JC, Chapron C, Bucella D, et al. Estrogen and progesterone receptors in smooth muscle component of deep infiltrating endometriosis. Fertility and sterility. 2010 Apr;93(6):1774-7. doi: 10.1016/j.fertnstert.2008.12.114. PubMed PMID: 19217090; eng.

16. McKinnon BD, Bertschi D, Bersinger NA, et al. Inflammation and nerve fiber interaction in endometriotic pain. Trends Endocrinol Metab. 2015 Jan;26(1):1-10. doi:

10.1016/j.tem.2014.10.003. PubMed PMID: 25465987. 
17. Tafi E, Leone Roberti Maggiore U, Alessandri F, et al. Advances in pharmacotherapy for treating endometriosis. Expert Opin Pharmacother. 2015 Nov;16(16):2465-83. doi:

10.1517/14656566.2015.1085510. PubMed PMID: 26569155.

18. Ferrero S, Alessandri F, Racca A, et al. Treatment of pain associated with deep endometriosis: alternatives and evidence. Fertility and sterility. 2015 Oct;104(4):771-92. doi: 10.1016/j.fertnstert.2015.08.031. PubMed PMID: 26363387.

19. DiVasta AD, Laufer MR. The use of gonadotropin releasing hormone analogues in adolescent and young patients with endometriosis. Curr Opin Obstet Gynecol. 2013 Aug;25(4):28792. doi: 10.1097/GCO.0b013e32836343eb. PubMed PMID: 23770813.

20. Ferrero S, Remorgida V, Maganza C, et al. Aromatase and endometriosis: estrogens play a role. Ann N Y Acad Sci. 2014 May;1317:17-23. doi: 10.1111/nyas.12411. PubMed PMID: 24738993.

21. Reis FM, Petraglia F, Taylor RN. Endometriosis: hormone regulation and clinical consequences of chemotaxis and apoptosis. Human reproduction update. 2013 Jul-Aug;19(4):40618. doi: 10.1093/humupd/dmt010. PubMed PMID: 23539633; PubMed Central PMCID: PMCPMC3682670.

22. Grandi G, Mueller MD, Bersinger NA, et al. The association between progestins, nuclear receptors expression and inflammation in endometrial stromal cells from women with endometriosis. (1473-0766 (Electronic)). eng.

23. Grandi G, Mueller M, Bersinger N, et al. Progestin suppressed inflammation and cell viability of tumor necrosis factor-alpha-stimulated endometriotic stromal cells. Am J Reprod Immunol. 2016 Oct;76(4):292-8. doi: 10.1111/aji.12552. PubMed PMID: 27515307.

24. Katayama H, Katayama T, Uematsu K, et al. Effect of dienogest administration on angiogenesis and hemodynamics in a rat endometrial autograft model. Hum Reprod. 2010 Nov;25(11):2851-8. doi: 10.1093/humrep/deq241. PubMed PMID: 20813806.

25. Schweppe KW. Current place of progestins in the treatment of endometriosis-related complaints. Gynecol Endocrinol. 2001 Dec;15 Suppl 6:22-8. PubMed PMID: 12227883.

26. Ferrero S, Remorgida V, Venturini PL. Current pharmacotherapy for endometriosis. Expert Opin Pharmacother. 2010 May;11(7):1123-34. doi: 10.1517/14656561003685880. PubMed PMID: 20230308.

27. Berlanda N, Somigliana E, Vigano P, et al. Safety of medical treatments for endometriosis. Expert Opin Drug Saf. 2016 Jan;15(1):21-30. doi: 10.1517/14740338.2016.1121991. PubMed PMID: 26576479.

28. Chwalisz K, Surrey E, Stanczyk FZ. The hormonal profile of norethindrone acetate: rationale for add-back therapy with gonadotropin-releasing hormone agonists in women with endometriosis. Reprod Sci. 2012 Jun;19(6):563-71. doi: 10.1177/1933719112438061. PubMed PMID: 22457429.

29. Singh H, Uniyal JP, Jha P, et al. Pharmacokinetics of norethindrone acetate in women. American journal of obstetrics and gynecology. 1979 Oct 1;135(3):409-14. PubMed PMID: 484634.

30. Prasad KV, Rao BS, Sivakumar B, et al. Pharmacokinetics of norethindrone in Indian Women, Contraception. 1979 Jul;20(1):77-90. PubMed PMID: 477319.

31. Food and Drugs Administration. AYGESTIN ${ }^{\circledR}$ (norethindrone acetate) tablets, USP. Available from: https://www.accessdata.fda.gov/drugsatfda docs/label/2007/018405s023lbl.pdf 32. Chu MC, Zhang X, Gentzschein E, et al. Formation of ethinyl estradiol in women during treatment with norethindrone acetate. Journal of Clinical Endocrinology and Metabolism. 2007;92(6):2205-2207. doi: 10.1210/jc.2007-0044.

33. Vercellini P, Pietropaolo G, De Giorgi O, et al. Treatment of symptomatic rectovaginal endometriosis with an estrogen-progestogen combination versus low-dose norethindrone acetate. Fertility and sterility. 2005;84(5):1375-1387. doi: 10.1016/j.fertnstert.2005.03.083. 
34. Vercellini P, Somigliana E, Consonni D, et al. Surgical versus medical treatment for endometriosis-associated severe deep dyspareunia: I. Effect on pain during intercourse and patient satisfaction. Human Reproduction. 2012;27(12):3450-3459. doi: 10.1093/humrep/des313.

35. Ferrero S, Camerini G, Ragni N, et al. Norethisterone acetate in the treatment of colorectal endometriosis: A pilot study. Human Reproduction. 2010;25(1):94-100. doi:

10.1093/humrep/dep361.

36. Ferrero S, Remorgida V, Venturini PL, et al. Norethisterone acetate versus norethisterone acetate combined with letrozole for the treatment of ovarian endometriotic cysts: a patient preference study. Eur J Obstet Gynecol Reprod Biol. 2014 Mar;174:117-22. doi:

10.1016/j.ejogrb.2013.11.030. PubMed PMID: 24388845.

37. Morotti M, Venturini PL, Biscaldi E, et al. Efficacy and acceptability of long-term norethindrone acetate for the treatment of rectovaginal endometriosis. Eur J Obstet Gynecol Reprod Biol. 2017 Mar 27;213:4-10. doi: 10.1016/j.ejogrb.2017.03.033. PubMed PMID: 28384540.

38. Scala C, Leone Roberti Maggiore U, Barra F, et al. Norethindrone acetate versus extendedcycle oral contraceptive (Seasonique $((\mathrm{R}))$ ) in the treatment of endometriosis symptoms: A prospective open-label comparative study. Eur J Obstet Gynecol Reprod Biol. 2018 Feb 1;222:8994. doi: 10.1016/j.ejogrb.2018.01.022. PubMed PMID: 29408753.

39. Vercellini P, Pietropaolo G, De Giorgi O, et al. Treatment of symptomatic rectovaginal endometriosis with an estrogen-progestogen combination versus low-dose norethindrone acetate. Fertility and sterility. 2005 Nov;84(5):1375-87. doi: 10.1016/j.fertnstert.2005.03.083. PubMed PMID: 16275232.

40. Neumann F. Pharmacology and potential use of cyproterone acetate. Horm Metab Res. 1977 Jan;9(1):1-13. doi: 10.1055/s-0028-1093574. PubMed PMID: 66176.

41. Hümpel M, Wendt $H$, Dogs $G$, et al. Intraindividual comparison of pharmacokinetic parameters of d-norgestrel, lynestrenol and cyproterone acetate in 6 women. Contraception. 1977 1977/08/01/;16(2):199-215. doi: 10.1016/0010-7824(77)90087-7.

42. Frolich M, van Schie MG, Brand EC. Sex hormone binding globulin: binding capacity and studies on the binding of cyproterone acetate and other steroids. Clin Chim Acta. 1978 Jul 15;87(2):239-44. PubMed PMID: 566170.

43. Moran C, Alcivia JC, Garcia-Hernandez E, et al. Treatment of endometriosis with cyproterone acetate. Preliminary report. Archives of Medical Research. 1996;27(4):535-538.

44. Vercellini P, De Giorgi O, Mosconi P, et al. Cyproterone acetate versus a continuous monophasic oral contraceptive in the treatment of recurrent pelvic pain after conservative surgery for symptomatic endometriosis. Fertility and sterility. 2002;77(1):52-61. doi: 10.1016/S00150282(01)02951-X.

45. Stone SC. Desogestrel. Clinical obstetrics and gynecology. 1995 Dec;38(4):821-8. PubMed PMID: 8616978.

46. Scala C, Leone Roberti Maggiore U, Remorgida V, et al. Drug safety evaluation of desogestrel. Expert Opin Drug Saf. 2013 May;12(3):433-44. doi: 10.1517/14740338.2013.788147. PubMed PMID: 23560561.

47. Hasenack HG, Bosch AM, Kaar K. Serum levels of 3-keto-desogestrel after oral administration of desogestrel and 3-keto-desogestrel. Contraception. 1986 Jun;33(6):591-6. PubMed PMID: 2945700.

48. Madden S, Back DJ, Martin CA, et al. Metabolism of the contraceptive steroid desogestrel by the intestinal mucosa. Br J Clin Pharmacol. 1989 Mar;27(3):295-9. PubMed PMID: 2524206; PubMed Central PMCID: PMCPMC1379826.

49. Back DJ, Grimmer SF, Shenoy N, et al. Plasma concentrations of 3-keto-desogestrel after oral administration of desogestrel and intravenous administration of 3-keto-desogestrel.

Contraception. 1987 Jun;35(6):619-26. PubMed PMID: 2959449. 
50. Kuhnz W, Pfeffer M, al-Yacoub G. Protein binding of the contraceptive steroids gestodene, 3-keto-desogestrel and ethinylestradiol in human serum. J Steroid Biochem. 1990 Feb;35(2):313-8. PubMed PMID: 2308344.

51. Verhoeven CH, Gloudemans RH, Peeters PA, et al. Excretion and metabolism of desogestrel in healthy postmenopausal women. J Steroid Biochem Mol Biol. 2001 Nov;78(5):471-80. PubMed PMID: 11738557.

52. Razzi S, Luisi S, Ferretti C, et al. Use of a progestogen only preparation containing desogestrel in the treatment of recurrent pelvic pain after conservative surgery for endometriosis. European Journal of Obstetrics Gynecology and Reproductive Biology. 2007;135(2):188-190. doi: 10.1016/j.ejogrb.2006.08.002.

53. Remorgida V, Abbamonte LH, Ragni N, et al. Letrozole and desogestrel-only contraceptive pill for the treatment of stage IV endometriosis. Australian and New Zealand Journal of Obstetrics and Gynaecology. 2007;47(3):222-225. doi: 10.1111/j.1479-828X.2007.00722.x.

54. Maggiore ULR, Remorgida V, Scala C, et al. Desogestrel-only contraceptive pill versus sequential contraceptive vaginal ring in the treatment of rectovaginal endometriosis infiltrating the rectum: A prospective open-label comparative study. Acta Obstetricia et Gynecologica Scandinavica. 2014;93(3):239-247. doi: 10.1111/aogs.12326.

55. Morotti M, Remorgida V, Venturini PL, et al. Progestin-only contraception compared with extended combined oral contraceptive in women with migraine without aura: A retrospective pilot study. European Journal of Obstetrics Gynecology and Reproductive Biology. 2014;183:178-182. doi: 10.1016/j.ejogrb.2014.10.029.

56. Ferrero S, Pretta S, Bertoldi S, et al. Increased frequency of migraine among women with endometriosis. Hum Reprod. 2004 Dec;19(12):2927-32. doi: 10.1093/humrep/deh537. PubMed PMID: 15513980.

57. Food and Drugs Administration. MPLANON® (etonogestrel implant) $68 \mathrm{mg}$ For Subdermal Use Only. Available from:

https://www.accessdata.fda.gov/drugsatfda docs/label/2009/021529s004lbl.pdf

58. Bennink HJ. The pharmacokinetics and pharmacodynamics of Implanon, a single-rod etonogestrel contraceptive implant. Eur J Contracept Reprod Health Care. 2000 Sep;5 Suppl 2:1220. PubMed PMID: 11246602.

59. Wenzl R, van Beek A, Schnabel P, et al. Pharmacokinetics of etonogestrel released from the contraceptive implant Implanon. Contraception. 1998 Nov;58(5):283-8. PubMed PMID: 9883383.

60. Ponpuckdee J, Taneepanichskul S. The effects of implanon in the symptomatic treatment of endometriosis. Journal of the Medical Association of Thailand = Chotmaihet thangphaet. 2005 Oct;88 Suppl 2:S7-10. PubMed PMID: 17722311; eng.

61. Walch K, Unfried G, Huber J, et al. Implanon versus medroxyprogesterone acetate: effects on pain scores in patients with symptomatic endometriosis--a pilot study. Contraception. 2009 Jan;79(1):29-34. doi: 10.1016/j.contraception.2008.07.017. PubMed PMID: 19041438. 62. Beerthuizen R, van Beek A, Massai R, et al. Bone mineral density during long-term use of the progestagen contraceptive implant Implanon compared to a non-hormonal method of contraception. Hum Reprod. 2000 Jan;15(1):118-22. PubMed PMID: 10611199.

63. Monteiro-Dantas C, Espejo-Arce X, Lui-Filho JF, et al. A three-year longitudinal evaluation of the forearm bone density of users of etonogestrel- and levonorgestrel-releasing contraceptive implants. Reprod Health. 2007 Nov 12;4:11. doi: 10.1186/1742-4755-4-11. PubMed PMID: 17997844; PubMed Central PMCID: PMCPMC2200638.

64. Westhoff C. Depot-medroxyprogesterone acetate injection (Depo-Provera): a highly effective contraceptive option with proven long-term safety. Contraception. 2003 Aug;68(2):75-87. PubMed PMID: 12954518.

65. Dragoman MV, Gaffield ME. The safety of subcutaneously administered depot medroxyprogesterone acetate $(104 \mathrm{mg} / 0.65 \mathrm{~mL})$ : A systematic review. Contraception. 2016 Sep;94(3):202-15. doi: 10.1016/j.contraception.2016.02.003. PubMed PMID: 26874275. 
66. Ruan X, Seeger H, Mueck AO. The pharmacology of dienogest. Maturitas. 2012 Apr;71(4):337-44. doi: 10.1016/j.maturitas.2012.01.018. PubMed PMID: 22364708.

67. Food and Drugs Administration. PROVERA ${ }^{\circledR}$ (medroxyprogesterone acetate) tablets, USP. Available from:

https://www.accessdata.fda.gov/drugsatfda_docs/label/2015/011839s079s080lbl.pdf

68. Food and Drugs Administration. DEPO-PROVERA CI $\AA$ (medroxyprogesterone acetate) injectable suspension, for intramuscular use. Available from:

https://www.accessdata.fda.gov/drugsatfda docs/label/2010/020246s036lbl.pdf

69. Halpern V, Combes SL, Dorflinger LJ, et al. Pharmacokinetics of subcutaneous depot

medroxyprogesterone acetate injected in the upper arm. Contraception. 2014 2014/01/01/;89(1):31-

35. doi: 10.1016/j.contraception.2013.07.002.

70. Roland M, Leisten D, Kane R. Endometriosis therapy with medroxyprogesterone acetate.

The Journal of reproductive medicine. 1976 Oct;17(4):249-52. PubMed PMID: 978656.

71. Moghissi KS, Boyce CR. Management of endometriosis with oral medroxyprogesterone acetate. Obstet Gynecol. 1976 Mar;47(3):265-7. PubMed PMID: 1250555.

72. Luciano AA, Turksoy RN, Carleo J. Evaluation of oral medroxyprogesterone acetate in the treatment of endometriosis. Obstet Gynecol. 1988 Sep;72(3 Pt 1):323-7. PubMed PMID: 2970029.

73. Telimaa S, Puolakka J, Ronnberg L, et al. Placebo-controlled comparison of danazol and high-dose medroxyprogesterone acetate in the treatment of endometriosis. Gynecol Endocrinol. 1987 Mar;1(1):13-23. doi: 10.3109/09513598709082692. PubMed PMID: 2972167.

74. Telimaa S, Ronnberg L, Kauppila A. Placebo-controlled comparison of danazol and highdose medroxyprogesterone acetate in the treatment of endometriosis after conservative surgery. Gynecol Endocrinol. 1987 Dec;1(4):363-71. PubMed PMID: 2972171.

75. Bergqvist A, Theorell T. Changes in quality of life after hormonal treatment of endometriosis. Acta Obstet Gynecol Scand. 2001 Jul;80(7):628-37. PubMed PMID: 11437721. 76. Harrison RF, Barry-Kinsella C. Efficacy of medroxyprogesterone treatment in infertile women with endometriosis: a prospective, randomized, placebo-controlled study. Fertility and sterility. 2000 Jul;74(1):24-30. PubMed PMID: 10899492.

77. Brown J, Kives S, Akhtar M. Progestagens and anti-progestagens for pain associated with endometriosis. Cochrane Database Syst Rev. 2012 (3):CD002122. doi:

10.1002/14651858.CD002122.pub2. PubMed PMID: 22419284.

78. Vercellini P, De Giorgi O, Oldani S, et al. Depot medroxyprogesterone acetate versus an oral contraceptive combined with very-low-dose danazol for long-term treatment of pelvic pain associated with endometriosis. American journal of obstetrics and gynecology. 1996;175(2):396401. doi: 10.1016/S0002-9378(96)70152-7.

79. Wong AYK, Tang LCH, Chin RKH. Levonorgestrel-releasing intrauterine system (Mirena ${ }^{\circledR}$ ) and Depot medroxyprogesterone acetate (Depoprovera) as long-term maintenance therapy for patients with moderate and severe endometriosis: A randomised controlled trial. Australian and New Zealand Journal of Obstetrics and Gynaecology. 2010;50(3):273-279. doi: 10.1111/j.1479-828X.2010.01152.x.

80. Crosignani PG, Luciano A, Ray A, et al. Subcutaneous depot medroxyprogesterone acetate versus leuprolide acetate in the treatment of endometriosis-associated pain. Human Reproduction. 2006;21(1):248-256. doi: 10.1093/humrep/dei290.

81. Schlaff WD, Carson SA, Luciano A, et al. Subcutaneous injection of depot medroxyprogesterone acetate compared with leuprolide acetate in the treatment of endometriosisassociated pain. Fertility and sterility. 2006;85(2):314-325. doi: 10.1016/j.fertnstert.2005.07.1315. 82. Stager MM, Cromer BA. Management of clinical side effects of DMPA. J Pediatr Adolesc Gynecol. 2000 Aug;13(3):147-9. PubMed PMID: 10989335.

83. Jain J, Jakimiuk AJ, Bode FR, et al. Contraceptive efficacy and safety of DMPA-SC. Contraception. 2004 Oct;70(4):269-75. doi: 10.1016/j.contraception.2004.06.011. PubMed PMID: 15451329. 
84. Kaunitz AM, Darney PD, Ross D, et al. Subcutaneous DMPA vs. intramuscular DMPA: a 2year randomized study of contraceptive efficacy and bone mineral density. Contraception. 2009;80(1):7-17. doi: 10.1016/j.contraception.2009.02.005.

85. Guilbert ER, Brown JP, Kaunitz AM, et al. The use of depot-medroxyprogesterone acetate in contraception and its potential impact on skeletal health. Contraception. 2009 Mar;79(3):167-77. doi: 10.1016/j.contraception.2008.10.016. PubMed PMID: 19185668.

86. Gynecologists TACoOa. COMMITTE OPINION - Depot Medroxyprogesterone Acetate and Bone Effects. 2014.

87. Harada T, Taniguchi F. Dienogest: a new therapeutic agent for the treatment of endometriosis. Womens Health (Lond). 2010 Jan;6(1):27-35. doi: 10.2217/whe.09.72. PubMed PMID: 20001868.

88. Board ME. PUBLIC ASSESSMENT REPORT of the Medicines Evaluation Board in the Netherlands Visanne, tablets, 2 mg Bayer BV, The Netherlands. Available from: https://db.cbgmeb.nl/Pars/h104058.pdf

89. McCormack PL. Dienogest: a review of its use in the treatment of endometriosis. Drugs. 2010 Nov 12;70(16):2073-88. doi: 10.2165/11206320-000000000-00000. PubMed PMID: 20964453.

90. Shin D, Lee S, Lim KS, et al. Pharmacokinetic study of single and multiple oral administrations of $2 \mathrm{mg}$ dienogest in healthy Korean women. Contraception. $2013 \mathrm{Jun} ; 87(6): 750-5$. doi: 10.1016/j.contraception.2012.10.033. PubMed PMID: 23218856; eng.

91. Bizzarri N, Remorgida V, Leone Roberti Maggiore U, et al. Dienogest in the treatment of endometriosis. Expert Opin Pharmacother. 2014 Sep;15(13):1889-902. doi:

10.1517/14656566.2014.943734. PubMed PMID: 25069386.

92. Andres Mde P, Lopes LA, Baracat EC, et al. Dienogest in the treatment of endometriosis: systematic review. Arch Gynecol Obstet. 2015 Sep;292(3):523-9. doi: 10.1007/s00404-015-3681-6. PubMed PMID: 25749349; eng.

93. Kitawaki J, Kusuki I, Yamanaka K, et al. Maintenance therapy with dienogest following gonadotropin-releasing hormone agonist treatment for endometriosis-associated pelvic pain. Eur J Obstet Gynecol Reprod Biol. 2011 Aug;157(2):212-6. doi: 10.1016/j.ejogrb.2011.03.012. PubMed PMID: 21474232.

94. Lang J, Yu Q, Zhang S, et al. Dienogest for Treatment of Endometriosis in Chinese Women: A Placebo-Controlled, Randomized, Double-Blind Phase 3 Study. J Womens Health (Larchmt). 2017 Oct 30. doi: 10.1089/jwh.2017.6399. PubMed PMID: 29083258; eng.

95. Morotti M, Sozzi F, Remorgida V, et al. Dienogest in women with persistent endometriosisrelated pelvic pain during norethisterone acetate treatment. Eur J Obstet Gynecol Reprod Biol. 2014 Dec;183:188-92. doi: 10.1016/j.ejogrb.2014.10.036. PubMed PMID: 25461377.

96. Leone Roberti Maggiore U, Ferrero S, Candiani M, et al. Bladder Endometriosis: A Systematic Review of Pathogenesis, Diagnosis, Treatment, Impact on Fertility, and Risk of Malignant Transformation. Eur Urol. 2017 May;71(5):790-807. doi: 10.1016/j.eururo.2016.12.015. PubMed PMID: 28040358.

97. Angioni S, Nappi L, Pontis A, et al. Dienogest. A possible conservative approach in bladder endometriosis. Results of a pilot study. Gynecological Endocrinology. 2015;31(5):406-408. doi: 10.3109/09513590.2015.1006617.

98. Leonardo-Pinto JP, Benetti-Pinto CL, Cursino K, et al. Dienogest and deep infiltrating endometriosis: The remission of symptoms is not related to endometriosis nodule remission. European Journal of Obstetrics Gynecology and Reproductive Biology. 2017;211:108-111. doi: 10.1016/j.ejogrb.2017.02.015.

99. Vercellini P, Bracco B, Mosconi P, et al. Norethindrone acetate or dienogest for the treatment of symptomatic endometriosis: a before and after study. Fertility and sterility. 2015 Dec 8. doi: 10.1016/j.fertnstert.2015.11.016. PubMed PMID: 26677792. 
100. Strowitzki T, Faustmann T, Gerlinger C, et al. Safety and tolerability of dienogest in endometriosis: Pooled analysis from the European clinical study program. International Journal of Women's Health. 2015;7:391-401. doi: 10.2147/IJWH.S77202.

101. Lee DY, Lee JY, Seo JW, et al. Gonadotropin-releasing hormone agonist with add-back treatment is as effective and tolerable as dienogest in preventing pain recurrence after laparoscopic surgery for endometriosis. Archives of Gynecology and Obstetrics. 2016;294(6):1257-1263. doi: 10.1007/s00404-016-4184-9.

102. Momoeda M, Harada T, Terakawa N, et al. Long-term use of dienogest for the treatment of endometriosis. Journal of Obstetrics and Gynaecology Research. 2009;35(6):1069-1076. doi: 10.1111/j.1447-0756.2009.01076.x.

103. Strowitzki T, Marr J, Gerlinger C, et al. Dienogest is as effective as leuprolide acetate in treating the painful symptoms of endometriosis: A 24-week, randomized, multicentre, open-label trial. Human Reproduction. 2010;25(3):633-641. doi: 10.1093/humrep/dep469.

104. Vercellini P, Vigano P, Somigliana E. The role of the levonorgestrel-releasing intrauterine device in the management of symptomatic endometriosis. Curr Opin Obstet Gynecol. 2005 Aug;17(4):359-65. PubMed PMID: 15976541.

105. Food and Drugs Administration. MIRENA ${ }^{\circledR}$ (levonorgestrel-releasing intrauterine system). Available from: https://www.accessdata.fda.gov/drugsatfda docs/label/2008/021225s019lbl.pdf

106. Seeber B, Ziehr SC, Gschliebetaer A, et al. Quantitative levonorgestrel plasma level measurements in patients with regular and prolonged use of the levonorgestrel-releasing intrauterine system. Contraception. 2012 Oct;86(4):345-9. doi: 10.1016/j.contraception.2012.01.015. PubMed PMID: 22402256.

107. Gomes MKO, Rosa-E-Silva JC, Garcia SB, et al. Effects of the levonorgestrel-releasing intrauterine system on cell proliferation, Fas expression and steroid receptors in endometriosis lesions and normal endometrium. Human Reproduction. 2009;24(11):2736-2745. doi: 10.1093/humrep/dep288.

108. Engemise SL, Willets JM, Taylor AH, et al. Changes in glandular and stromal estrogen and progesterone receptor isoform expression in eutopic and ectopic endometrium following treatment with the levonorgestrel-releasing intrauterine system. European Journal of Obstetrics Gynecology and Reproductive Biology. 2011;157(1):101-106. doi: 10.1016/j.ejogrb.2011.02.013.

109. Fedele L, Bianchi S, Zanconato G, et al. Use of a levonorgestrel-releasing intrauterine device in the treatment of rectovaginal endometriosis. Fertility and sterility. 2001;75(3):485-488. doi: 10.1016/S0015-0282(00)01759-3.

110. Petta CA, Ferriani RA, Abrao MS, et al. Randomized clinical trial of a levonorgestrelreleasing intrauterine system and a depot $\mathrm{GnRH}$ analogue for the treatment of chronic pelvic pain in women with endometriosis. Human Reproduction. 2005;20(7):1993-1998. doi:

10.1093/humrep/deh869.

111. Lan S, Ling L, Jianhong Z, et al. Analysis of the levonorgestrel-releasing intrauterine system in women with endometriosis. J Int Med Res. 2013 Jun;41(3):548-58. doi:

10.1177/0300060513479865. PubMed PMID: 23660087.

112. Lockhat FB, Emembolu JO, Konje JC. The efficacy, side-effects and continuation rates in women with symptomatic endometriosis undergoing treatment with an intra-uterine administered progestogen (levonorgestrel): a 3 year follow-up. Hum Reprod. 2005 Mar;20(3):789-93. doi:

10.1093/humrep/deh650. PubMed PMID: 15608040; eng.

113. Tanmahasamut P, Rattanachaiyanont M, Angsuwathana S, et al. Postoperative levonorgestrel-releasing intrauterine system for pelvic endometriosis-related pain: a randomized controlled trial. Obstet Gynecol. 2012 Mar;119(3):519-26. doi: 10.1097/AOG.0b013e31824264c3. PubMed PMID: 22314873.

114. Morelli M, Sacchinelli A, Venturella R, et al. Postoperative administration of dienogest plus estradiol valerate versus levonorgestrel-releasing intrauterine device for prevention of pain relapse 
and disease recurrence in endometriosis patients. J Obstet Gynaecol Res. 2013 May;39(5):985-90. doi: 10.1111/jog.12030. PubMed PMID: 23551827; eng.

115. Cho S, Jung JA, Lee Y, et al. Postoperative levonorgestrel-releasing intrauterine system versus oral contraceptives after gonadotropin-releasing hormone agonist treatment for preventing endometrioma recurrence. Acta Obstet Gynecol Scand. 2014 Jan;93(1):38-44. PubMed PMID: 24605384; eng.

116. Kim ML, Cho YJ, Kim MK, et al. The efficacy of long-term maintenance therapy with a levonorgestrel-releasing intrauterine system for prevention of ovarian endometrioma recurrence. International journal of gynaecology and obstetrics: the official organ of the International Federation of Gynaecology and Obstetrics. 2016 Sep;134(3):256-9. doi:

10.1016/j.ijgo.2016.03.017. PubMed PMID: 27346551; eng.

117. Chen YJ, Hsu TF, Huang BS, et al. Postoperative maintenance levonorgestrel-releasing intrauterine system and endometrioma recurrence: a randomized controlled study. American journal of obstetrics and gynecology. 2017 Jun;216(6):582.e1-582.e9. doi: 10.1016/j.ajog.2017.02.008. PubMed PMID: 28209488; eng.

118. Bayoglu Tekin Y, Dilbaz B, Altinbas SK, et al. Postoperative medical treatment of chronic pelvic pain related to severe endometriosis: levonorgestrel-releasing intrauterine system versus gonadotropin-releasing hormone analogue. Fertility and sterility. 2011 Feb;95(2):492-6. doi: 10.1016/j.fertnstert.2010.08.042. PubMed PMID: 20883991.

119. Ferrero S. Endometriosis: Modern management of an ancient disease. Eur J Obstet Gynecol Reprod Biol. 2017 Feb;209:1-2. doi: 10.1016/j.ejogrb.2016.12.036. PubMed PMID: 28094070.

120. Guerriero S, Condous G, Van den Bosch T, et al. Systematic approach to sonographic evaluation of the pelvis in women with suspected endometriosis, including terms, definitions and measurements: a consensus opinion from the International Deep Endometriosis Analysis (IDEA) group. Ultrasound Obstet Gynecol. 2016 Jun 28. doi: 10.1002/uog.15955. PubMed PMID: 27349699.

121. Morotti M, Remorgida V, Venturini PL, et al. Progestogen-only contraceptive pill compared with combined oral contraceptive in the treatment of pain symptoms caused by endometriosis in patients with migraine without aura. Eur J Obstet Gynecol Reprod Biol. 2014 Aug;179:63-8. doi: 10.1016/j.ejogrb.2014.05.016. PubMed PMID: 24965982.

122. Upson K, Allison KH, Reed SD, et al. Biomarkers of progestin therapy resistance and endometrial hyperplasia progression. Am J Obstet Gynecol. 2012 Jul;207(1):36 e1-8. doi: 10.1016/j.ajog.2012.05.012. PubMed PMID: 22727345; PubMed Central PMCID: PMCPMC3398620.

123. Clark MK, Sowers MR, Nichols S, et al. Bone mineral density changes over two years in first-time users of depot medroxyprogesterone acetate. Fertility and sterility. 2004 Dec;82(6):15806. doi: 10.1016/j.fertnstert.2004.04.064. PubMed PMID: 15589863.

124. Scholes D, LaCroix AZ, Ichikawa LE, et al. Change in bone mineral density among adolescent women using and discontinuing depot medroxyprogesterone acetate contraception. Arch Pediatr Adolesc Med. 2005 Feb;159(2):139-44. doi: 10.1001/archpedi.159.2.139. PubMed PMID: 15699307.

125. Modesto W, Bahamondes MV, Bahamondes L. Prevalence of Low Bone Mass and Osteoporosis in Long-Term Users of the Injectable Contraceptive Depot Medroxyprogesterone Acetate. J Womens Health (Larchmt). 2015 Aug;24(8):636-40. doi: 10.1089/jwh.2014.5077. PubMed PMID: 26098552.

126. Meier C, Brauchli YB, Jick SS, et al. Use of depot medroxyprogesterone acetate and fracture risk. J Clin Endocrinol Metab. 2010 Nov;95(11):4909-16. doi: 10.1210/jc.2010-0032. PubMed PMID: 20685865.

127. Lanza LL, McQuay LJ, Rothman KJ, et al. Use of depot medroxyprogesterone acetate contraception and incidence of bone fracture. Obstet Gynecol. 2013 Mar;121(3):593-600. doi: 10.1097/AOG.0b013e318283d1a1. PubMed PMID: 23635623. 
128. Vestergaard P, Rejnmark L, Mosekilde L. The effects of depot medroxyprogesterone acetate and intrauterine device use on fracture risk in Danish women. Contraception. 2008 Dec;78(6):45964. doi: 10.1016/j.contraception.2008.07.014. PubMed PMID: 19014791.

129. Pontis A, D'Alterio MN, Pirarba S, et al. Adenomyosis: a systematic review of medical treatment. Gynecol Endocrinol. 2016 Sep;32(9):696-700. doi: 10.1080/09513590.2016.1197200. PubMed PMID: 27379972.

130. Muzii L. Medicated intrauterine systems for treatment of endometriosis-associated pain. J Minim Invasive Gynecol. 2006 Nov-Dec;13(6):535-8. doi: 10.1016/j.jmig.2006.06.010. PubMed PMID: 17097576.

131. Cosson M, Querleu D, Donnez J, et al. Dienogest is as effective as triptorelin in the treatment of endometriosis after laparoscopic surgery: results of a prospective, multicenter, randomized study. Fertility and sterility. 2002 Apr;77(4):684-92. PubMed PMID: 11937116. 132. Harada T, Momoeda M, Taketani Y, et al. Dienogest is as effective as intranasal buserelin acetate for the relief of pain symptoms associated with endometriosis--a randomized, double-blind, multicenter, controlled trial. Fertility and sterility. 2009 Mar;91(3):675-81. doi:

10.1016/j.fertnstert.2007.12.080. PubMed PMID: 18653184.

133. Strowitzki T, Marr J, Gerlinger C, et al. Dienogest is as effective as leuprolide acetate in treating the painful symptoms of endometriosis: a 24-week, randomized, multicentre, open-label trial. Hum Reprod. 2010 Mar;25(3):633-41. doi: 10.1093/humrep/dep469. PubMed PMID: 20089522.

134. Takaesu Y, Nishi H, Kojima J, et al. Dienogest compared with gonadotropin-releasing hormone agonist after conservative surgery for endometriosis. J Obstet Gynaecol Res. 2016 Sep;42(9):1152-8. doi: 10.1111/jog.13023. PubMed PMID: 27225336.

135. Petta CA, Ferriani RA, Abrao MS, et al. Randomized clinical trial of a levonorgestrelreleasing intrauterine system and a depot GnRH analogue for the treatment of chronic pelvic pain in women with endometriosis. Hum Reprod. 2005 Jul;20(7):1993-8. doi: 10.1093/humrep/deh869. PubMed PMID: 15790607.

136. Gomes MK, Ferriani RA, Rosa e Silva JC, et al. The levonorgestrel-releasing intrauterine system and endometriosis staging. Fertility and sterility. 2007 May;87(5):1231-4. doi:

10.1016/j.fertnstert.2006.11.044. PubMed PMID: 17292364.

137. Ferreira RA, Vieira CS, Rosa ESJC, et al. Effects of the levonorgestrel-releasing intrauterine system on cardiovascular risk markers in patients with endometriosis: a comparative study with the GnRH analogue. Contraception. 2010 Feb;81(2):117-22. doi: 10.1016/j.contraception.2009.08.003. PubMed PMID: 20103448. 
Tables

Table 1. Available formulations of progestins for the treatment of endometriosis

\begin{tabular}{|c|c|c|c|c|c|c|c|}
\hline \multirow[t]{2}{*}{ Route of administration } & \multirow[t]{2}{*}{ Drug } & \multicolumn{6}{|c|}{ Biological activities } \\
\hline & & $\begin{array}{l}\text { Anti- } \\
\text { estrogenic }\end{array}$ & Estrogenic & & $\begin{array}{l}\text { Anti- } \\
\text { androgenic }\end{array}$ & $\begin{array}{l}\text { Gluco- } \\
\text { corticoid }\end{array}$ & $\begin{array}{l}\text { Anti- } \\
\text { mineracorticoid }\end{array}$ \\
\hline \multirow[t]{5}{*}{ Oral route } & NETA & + & + & + & - & - & - \\
\hline & $\mathrm{CPA}$ & + & - & $t$ & - & + & - \\
\hline & MPA & + & - & \pm & - & + & - \\
\hline & DGS & + & & + & - & - & - \\
\hline & DNG & \pm & \pm & - & + & - & - \\
\hline Depot injection & DMPA & + & - & \pm & - & + & - \\
\hline Subdermal implant & ETG & & - & + & - & - & - \\
\hline Intrauterine device & LNG-IL & + & - & + & - & - & - \\
\hline
\end{tabular}

$(+)$ effective; $( \pm)$ weakly effective; $(-)$ not effective 
$\mathrm{NETA}=$ norethindrone acetate, $\mathrm{CPA}=$ cyproterone acetate, $\mathrm{MPA}=$ medroxyprogesterone acetate, $\mathrm{DMPA}=$ depot medroxyprogesterone acetate,

DGS=desogestrel, $\mathrm{DNG}=$ dienogest, $\mathrm{ETG}=$ etonogestrel, $\mathrm{LNG}-\mathrm{IUD}=$ levonogestrel-intrauterine device

Table 2. Studies investigating long-acting progestogen systems for the treatment of endometriosis

\begin{tabular}{|c|c|c|c|c|c|c|}
\hline Author, year & Study design & Population & Regimen & Follow-up & Results & $\mathbf{A E}$ \\
\hline $\begin{array}{l}\text { Vercellini, } 1996 \\
\text { [78] }\end{array}$ & $\begin{array}{l}\text { Multicenter, } \\
\text { prospective, } \\
\text { randomized }\end{array}$ & $\begin{array}{l}80 \text { women with } \\
\text { confirmed diagnosis of } \\
\text { endometriosis }\end{array}$ & $\begin{array}{l}\text { DMPA-M (150 } \\
\text { mg) every } 3 \\
\text { months or COC } \\
\text { (ethinyl estradiol } \\
0.02 \mathrm{mg} \text {, } \\
\text { desogestrel } 0.15 \\
\text { mg) plus } \\
\text { danazol ( } 50 \mathrm{mg} \text { ) } \\
\text { for } 21 \text { days of } \\
\text { each } 28 \text {-day } \\
\text { cycle }\end{array}$ & & $\begin{array}{l}\text { Similar pain relief } \\
\text { at VAS in both } \\
\text { groups }\end{array}$ & $\begin{array}{l}\text { DMPA-M group: } \\
\text { spotting }(26 \%) \text {, } \\
\text { bloating }(25 \%), \\
\text { weight gain }(21 \%) \text {; } \\
\text { COC plus danazol } \\
\text { group: weight gain } \\
(30 \%) \text {, bloating } \\
(28 \%) \text {, headache } \\
(23 \%)\end{array}$ \\
\hline $\begin{array}{l}\text { Ponpuckdee, } 2005 \\
{[60]}\end{array}$ & $\begin{array}{l}\text { Single center, } \\
\text { prospective }\end{array}$ & $\begin{array}{l}50 \text { women with } \\
\text { recurrent pain after } \\
\text { surgical treatment }\end{array}$ & $\begin{array}{l}\text { ENG-subdermal } \\
\text { implant (68 mg) }\end{array}$ & 12 weeks & $\begin{array}{l}\text { Improvement of } \\
\text { pain at VAS } \\
(\mathrm{P}<.001) \text { and } \\
\text { menstrual } \\
\text { symptoms }(\mathrm{P}<.001)\end{array}$ & $\begin{array}{l}\text { Spotting (26\%), } \\
\text { intermenstrual } \\
\text { bleeding }(4 \%)\end{array}$ \\
\hline
\end{tabular}




\begin{tabular}{|c|c|c|c|c|c|c|}
\hline $\begin{array}{l}\text { Crosignani, } 2006 \\
\text { [80] }\end{array}$ & $\begin{array}{l}\text { Multicenter, } \\
\text { prospective, } \\
\text { randomized }\end{array}$ & $\begin{array}{l}300 \text { women with } \\
\text { confirmed diagnosis of } \\
\text { endometriosis }\end{array}$ & $\begin{array}{l}\text { DMPA-SC (104 } \\
\text { mg/0.65) or } \\
\text { leuprolide ( } 3.75 \\
\text { or } 11.25 \mathrm{mg} \\
\text { depot IM) every } \\
3 \text { months, for } 6 \\
\text { months }\end{array}$ & 18 months & $\begin{array}{l}\text { Similar pain relief } \\
\text { in both groups } \\
(\mathrm{P}<.001)\end{array}$ & $\begin{array}{l}\text { DMPA-SC group: } \\
\text { intermenstrual } \\
\text { bleeding }(12.5 \%) \text {, } \\
\text { nausea }(11.2 \%) \text {, hot } \\
\text { flushes }(5.9 \%) \text {; } \\
\text { Leuprolide group: hot } \\
\text { flushes }(16.8 \%) \text {, } \\
\text { nausea } 7 \%) \text {, headache } \\
(6.3 \%) \text {; } \\
\text { At } 12 \text {-months, in } \\
\text { DMPA-SC group } \\
\text { smaller reductions in } \\
\text { total hip and lumbar } \\
\text { spine BMD than in } \\
\text { leuprolide group (P< } \\
\text {.001) }\end{array}$ \\
\hline Schlaff, 2006 [81] & $\begin{array}{l}\text { Multicenter, } \\
\text { prospective, } \\
\text { randomized }\end{array}$ & $\begin{array}{l}274 \text { women with } \\
\text { confirmed diagnosis of } \\
\text { endometriosis }\end{array}$ & $\begin{array}{l}\text { DMPA-SC (104 } \\
\text { mg/0.65) or } \\
\text { leuprolide } \\
\text { (11.25 mg depot } \\
\text { IM) every } 3 \\
\text { months, for } 6 \\
\text { months }\end{array}$ & 12 months & $\begin{array}{l}\text { Similar pain relief } \\
\text { in both groups } \\
(\mathrm{P}<.001)\end{array}$ & $\begin{array}{l}\text { DMPA-SC group: } \\
\text { headache (7.7\%), } \\
\text { injection-site reaction } \\
(6.9 \%) \text {, intermenstrual } \\
\text { bleeding (5.4\%); } \\
\text { Leuprolide group: hot } \\
\text { flushes (11.1\%), } \\
\text { headache (6.3\%), } \\
\text { libido decrease } \\
(5.2 \%) \text {; } \\
\text { At 6-months, In } \\
\text { DMPA-SC group } \\
\text { smaller reductions in } \\
\text { BMD than in } \\
\text { leuprolide group (P< }\end{array}$ \\
\hline
\end{tabular}




\begin{tabular}{|l|l|l|l|l|l|l|}
\hline & & & & \\
\hline Walch, 2009 [61] & $\begin{array}{l}\text { Single center, } \\
\text { prospective, } \\
\text { randomized }\end{array}$ & $\begin{array}{l}\text { 41 patients with } \\
\text { confirmed diagnosis of } \\
\text { endometriosis }\end{array}$ & $\begin{array}{l}\text { ENG-subdermal } \\
\text { implant (68 mg) } \\
\text { or DMPA-SC } \\
(104 \mathrm{mg} / 0.65) \\
\text { every 3 months }\end{array}$ & 1 year & $\begin{array}{l}\text { Different, but not } \\
\text { statistically } \\
\text { significant, } \\
\text { improvement of } \\
\text { pain: 68\% in the } \\
\text { ENG-subdermal } \\
\text { implant group and } \\
53 \% \text { in the DMPA- } \\
\text { M group (P.36) }\end{array}$ & $\begin{array}{l}\text { ENG-subdermal } \\
\text { implant: breast } \\
\text { tenderness (24\%), } \\
\text { libido decrease (24\%), } \\
\text { headache (14\%); } \\
\text { headache (20\%), } \\
\text { breast tenderness } \\
(15 \%)\end{array}$ \\
\hline
\end{tabular}

$\mathrm{AE}=$ adverse event, DMPA-M= Intramuscular depot medroxyprogesterone acetate, DMPA-SC= Subcutaneous depot medroxyprogesterone acetate, $\mathrm{ENG}=$ etonogestrel, $\mathrm{VAS}=$ visual analogue scale

Table 3. Randomized comparative trials of dienogest for the treatment of endometriosis

\begin{tabular}{|c|c|c|c|c|c|}
\hline Author, year & Population & Regimen & Follow-up & Results & $\mathbf{A E}$ \\
\hline Cosson, 2002 [131] & $\begin{array}{l}120 \text { women with } \\
\text { confirmed grade } 2-4 \\
\text { (rAFS) endometriosis, } \\
\text { post-surgical treatment }\end{array}$ & $\begin{array}{l}\mathrm{DNG}(1 \mathrm{mg} / \text { day }) \text { or } \\
\text { triptorelin }(3.75 \mathrm{mg} \\
\mathrm{IM}) \text { every } 4 \text { weeks, for } \\
16 \text { weeks }\end{array}$ & 12 months & $\begin{array}{l}\text { Similar modification in } \\
\text { the implant rAFS score } \\
\text { at second laparoscopy } \\
\text { was } \\
\text { Different, but not } \\
\text { statistically significant, } \\
\text { satisfaction to the } \\
\text { treatment: } 34.5 \% \text { very } \\
\text { satisfied and } 51.7 \% \\
\text { satisfied in the DNG } \\
\text { group, } 30 \% \text { very }\end{array}$ & $\begin{array}{l}\text { DNG group: } \\
\text { intermenstrual bleeding } \\
(61.6 \%) \text {, hot flushes }(9 \text {. } \\
6 \%) \text {; } \\
\text { Leuprolide group: hot } \\
\text { flushes }(61.2 \%) \text {, } \\
\text { intermenstrual bleeding } \\
(25.6 \%)\end{array}$ \\
\hline
\end{tabular}




\begin{tabular}{|c|c|c|c|c|c|}
\hline & & & & $\begin{array}{l}\text { satisfied and } 50 \% \\
\text { satisfied in the } \\
\text { leuprolide group (P.39) }\end{array}$ & \\
\hline Harada, 2009 [132] & $\begin{array}{l}171 \text { patients with } \\
\text { confirmed endometriosis }\end{array}$ & $\begin{array}{l}\text { DNG }(2 \mathrm{mg} / \text { day }) \text { or } \\
\text { buserelin }(900 \mu \mathrm{g} / \text { day, } \\
\text { intranasally }) \text { every } 4 \\
\text { weeks }\end{array}$ & 6 months & $\begin{array}{l}\text { Similar pain relief and } \\
\text { improvement of QoL in } \\
\text { both groups }\end{array}$ & $\begin{array}{l}\text { DNG group: } \\
\text { intermenstrual bleeding } \\
(95 \%) \text {, hot flushes }(50 \%) \text {; } \\
\text { headache }(25 \%) \text {; } \\
\text { Leuprolide group: } \\
\text { intermenstrual bleeding } \\
(67 \%) \text {, hot flushes }(67 \%) \text {; } \\
\text { headache }(34 \%)\end{array}$ \\
\hline $\begin{array}{l}\text { Strowitzki, } 2010 \\
\text { [133] }\end{array}$ & $\begin{array}{l}252 \text { patients with } \\
\text { confirmed endometriosis }\end{array}$ & $\begin{array}{l}\text { DNG (2 mg/day) or } \\
\text { leuprolide ( } 3.5 \mathrm{mg} \\
\text { depot IM) every } 4 \\
\text { weeks, for } 24 \text { weeks }\end{array}$ & 6 months & $\begin{array}{l}\text { Similar pain relief at } \\
\text { VAS in both groups } \\
(\mathrm{P}=.0004) ; \text { more } \\
\text { improvement of QoL in } \\
\text { DNG group }\end{array}$ & $\begin{array}{l}\text { DNG group: headache } \\
(12.5 \%) \text {, weight gain } \\
(6.7 \%) \text {, depression }(5.0 \\
\%) \text {; } \\
\text { Leuprolide group: } \\
\text { headache }(19.5 \%) \text {, } \\
\text { depression }(8.6 \%) \text {, } \\
\text { sleep disorder }(7.8 \%)\end{array}$ \\
\hline & & & & & $\begin{array}{l}\text { Changes in mean lumbar } \\
\text { BMD }+0.25 \% \text { with DNG } \\
\text { and }-4.04 \% \text { with LA } \\
\text { subgroups }(\mathrm{P}=.0003)\end{array}$ \\
\hline Lee, 2016 [101] & $\begin{array}{l}64 \text { women with } \\
\text { confirmed endometriosis, } \\
\text { post-surgical treatment }\end{array}$ & $\begin{array}{l}\text { DNG ( } 2 \mathrm{mg} / \text { day }) \text { or } \\
\text { leuprolide ( } 3.75 \mathrm{mg} \\
\text { depot SC) plus add- } \\
\text { back therapy (1.0 } \\
\mathrm{mg} / \text { day of } \mathrm{E}_{2} \text { and } 0.5 \\
\mathrm{mg} \text { /day of NETA) }\end{array}$ & No follow-up & $\begin{array}{l}\text { Visual analogue scale } \\
\text { pain score decreased } \\
\text { significantly in both } \\
\text { groups }\end{array}$ & $\begin{array}{l}\text { DNG group: } \\
\text { intermenstrual bleeding } \\
\text { (53.8-55.6\%), hot flushes } \\
(11.1 \%) \text {; depression } \\
(11.1 \%) ; \\
\text { Leuprolide plus add-back }\end{array}$ \\
\hline
\end{tabular}




\begin{tabular}{|c|c|c|c|c|}
\hline & & $\begin{array}{l}\text { every } 4 \text { weeks, for } 24 \\
\text { weeks }\end{array}$ & & $\begin{array}{l}\text { therapy group: } \\
\text { intermenstrual bleeding } \\
(0.8-22.2 \%) \text {, hot flushes } \\
(11.5 \%) \text {, genital dryness } \\
(11.5 \%) \\
\text { Significant decline BMD } \\
\text { of the lumbar spine in } \\
\text { both treatment groups (- } \\
2.5 \% \text { for leuprolide plus } \\
\text { add-back and }-2.3 \% \\
\text { for DNG) }\end{array}$ \\
\hline $\begin{array}{l}\text { Takaesu, } 2016 \\
{[134]}\end{array}$ & $\begin{array}{l}111 \text { women with } \\
\text { confirmed endometriosis, } \\
\text { post-surgical treatment }\end{array}$ & $\begin{array}{l}\text { DNG (2 mg/day) or } \\
\text { goserelin (1.8 mg } \\
\text { depot IM) every } 4 \\
\text { weeks, for } 24 \text { weeks }\end{array}$ & $\begin{array}{l}\text { No significant } \\
\text { difference in the } \\
\text { postoperative } \\
\text { recurrence rate in both } \\
\text { groups; } \\
\text { Menstrual pain and } \\
\text { chronic pelvic pain } \\
\text { were significantly } \\
\text { improved in both } \\
\text { groups }\end{array}$ & $\begin{array}{l}\text { DNG group: } \\
\text { intermenstrual bleeding } \\
(100 \%) \text {, hot flushes } \\
(11 \%) \text {; headache }(9 \%) \text {; } \\
\text { Goserelin group: hot } \\
\text { flushes }(94 \%) \text {; } \\
\text { intermenstrual bleeding } \\
(6 \%) \text {, headache }(4 \%) ;\end{array}$ \\
\hline
\end{tabular}

$\mathrm{AE}=$ adverse event, $\mathrm{rAFS}=$ according to the Revised American Fertility Society, $\mathrm{QoL}=$ quality of life, $\mathrm{DNG}=$ dienogest, VAS=visual analogue scale, $\mathrm{IM}=$ intramuscular, $\mathrm{SC}=$ subcutaneous, $\mathrm{E}_{2}=$ estradiol, $\mathrm{NETA}=$ norethindrone

Table 4. Randomized comparative trials of levonorgestrel-intrauterine device for the prevention of the treatment of endometriosis

\begin{tabular}{|l|l|l|l|l|l|}
\hline Author, year & Population & Regimen & Follow-up & Results & AE \\
\hline
\end{tabular}




\begin{tabular}{|c|c|c|c|c|c|}
\hline Petta, 2005 [135] & $\begin{array}{l}82 \text { women with confirmed } \\
\text { endometriosis }\end{array}$ & $\begin{array}{l}\text { LNG-IUD or } \\
\text { leuprolide ( } 3.75 \mathrm{mg} \\
\text { depot IM) every } 28 \\
\text { days }\end{array}$ & 6 months & $\begin{array}{l}\text { Chronic pelvic pain } \\
\text { decreased significantly in } \\
\text { both groups; }\end{array}$ & $\begin{array}{l}\text { LNG-IUD group: } \\
\text { intermenstrual } \\
\text { bleeding ( } 71 \%) \text {; } \\
\text { Leuprolide group: } \\
\text { intermenstrual } \\
\text { bleeding }(34 \%)\end{array}$ \\
\hline Gomes, 2007 [136] & $\begin{array}{l}22 \text { patients with } \\
\text { confirmed endometriosis }\end{array}$ & $\begin{array}{l}\text { LNG-IUD or } \\
\text { leuprolide }(3.75 \mathrm{mg} \\
\text { depot IM) }\end{array}$ & 6 months & $\begin{array}{l}\text { Pain score were } \\
\text { significantly reduced in } \\
\text { both groups. }\end{array}$ & NR \\
\hline Wong, 2010 [79] & $\begin{array}{l}30 \text { women with confirmed } \\
\text { endometriosis, post- } \\
\text { surgical treatment }\end{array}$ & $\begin{array}{l}\text { LNG-IUD or DMPA } \\
\text { every } 28 \text { days }\end{array}$ & 36 months & $\begin{array}{l}\text { Pain score were } \\
\text { significantly reduced in } \\
\text { both groups; } \\
\text { No significant difference } \\
\text { in the postoperative } \\
\text { recurrence rate in both } \\
\text { groups. }\end{array}$ & $\begin{array}{l}\text { Irregular vaginal } \\
\text { bleeding was a } \\
\text { common observation } \\
\text { in both groups, but } \\
\text { the severity and } \\
\text { frequency were } \\
\text { worse in the DMPA } \\
\text { group } \\
\text { Significantly higher } \\
\text { mean DEXA T-score } \\
\text { over the lumbar spine } \\
\text { in the LNG-IUD } \\
\text { group compared with } \\
\text { DMPA Group }\end{array}$ \\
\hline Ferreira, 2010 [137] & $\begin{array}{l}44 \text { women with confirmed } \\
\text { endometriosis }\end{array}$ & $\begin{array}{l}\text { LNG-IUD or } \\
\text { leuprolide }(3.75 \mathrm{mg}\end{array}$ & 6 months & $\begin{array}{l}\text { Significant reduction in } \\
\text { pain score with no }\end{array}$ & NR \\
\hline
\end{tabular}




\begin{tabular}{|c|c|c|c|c|c|}
\hline & & $\begin{array}{l}\text { depot IM) every } 28 \\
\text { days }\end{array}$ & & $\begin{array}{l}\text { significant difference in } \\
\text { both groups }\end{array}$ & \\
\hline Bayoglu Tekin, 2011 [118] & $\begin{array}{l}40 \text { women with confirmed } \\
\text { severe endometriosis }\end{array}$ & $\begin{array}{l}\text { LNG-IUD or } \\
\text { goserelin }(3.75 \mathrm{mg} \\
\text { depot SC) every } 28 \\
\text { days }\end{array}$ & 36 weeks & $\begin{array}{l}\text { TEPS decreased in the } \\
\text { LNG-IUD group at } 1,3 \text {, } \\
\text { and } 6 \text { months follow-up } \\
\text { visits, but at } 12 \text { months } \\
\text { of follow-up TESP } \\
\text { scores were increased to } \\
\text { values similar to } \\
\text { pretreatment values. } \\
\text { Goserelin group showed } \\
\text { a significant decrease in } \\
\text { the VAS score and TEPS } \\
\text { at the end of } 1 \text { year; } \\
\text { The patients in the LNG- } \\
\text { IUD group showed a } \\
\text { lower satisfaction to the } \\
\text { treatment than in the } \\
\text { goserelin group. }\end{array}$ & $\begin{array}{l}\text { LNG-IUD group: } \\
\text { intermenstrual } \\
\text { bleeding }(71 \%) \text {; } \\
\text { simple ovarian cysts } \\
(55 \%) \text {, One-sided } \\
\text { lower abdominal } \\
\text { pain }(40 \%) ; \\
\text { Goserelin group: } \\
\text { Vasomotor } \\
\text { symptoms }(55 \%) \text {, } \\
\text { amenorrhea }(30 \%) \text {, } \\
\text { weight gain }(5 \%)\end{array}$ \\
\hline $\begin{array}{l}\text { Tanmahasamut, } 2012 \\
\text { [113] }\end{array}$ & $\begin{array}{l}55 \text { women with confirmed } \\
\text { endometriosis, post- } \\
\text { surgical treatment }\end{array}$ & $\begin{array}{l}\text { LNG-IUD or } \\
\text { expectant } \\
\text { management }\end{array}$ & 12 months & $\begin{array}{l}\text { In the LNG-IUD group } \\
\text { there was a greater } \\
\text { reduction in } \\
\text { dysmenorrhea }(\mathrm{P}=.006) \text {, } \\
\text { pelvic pain }(\mathrm{P}=.038) \\
\text { VAS but a comparable } \\
\text { reduction in dyspareunia } \\
\text { VAS }(\mathrm{P}=.831)\end{array}$ & $\begin{array}{l}\text { LNG-IUD group: } \\
\text { intermenstrual } \\
\text { bleeding }(37 \%) \text {, acne } \\
(59.3 \%) \text {, oily skin } \\
(74.1 \%) \text {; } \\
\text { Expectant } \\
\text { management group: } \\
\text { intermenstrual } \\
\text { bleeding }(69.6 \%) \\
\text { acne }(56.5 \%) \text {, oily } \\
\text { skin }(69.6 \%)\end{array}$ \\
\hline
\end{tabular}




\begin{tabular}{|c|c|c|c|c|c|}
\hline Chen, 2017 [117] & $\begin{array}{l}80 \text { patients with } \\
\text { endometriomas } \\
\text { undergoing laparoscopic } \\
\text { cystectomy }\end{array}$ & $\begin{array}{l}\text { LNG-IUD plus } \\
\text { leuprolide ( } 3.75 \mathrm{mg} \\
\text { depot IM) every } 28 \\
\text { days or leuprolide } \\
\text { (3.75 mg depot IM) } \\
\text { every } 28 \text { days plus }\end{array}$ & 30 months & $\begin{array}{l}\text { Endometrioma } \\
\text { recurrence did not } \\
\text { significantly differ in } \\
\text { both groups; } \\
\text { lower dysmenorrhea } \\
\text { recurrence and higher the } \\
\text { dysmenorrhea VAS } \\
\text { reduction in the LNG- } \\
\text { IUD plus leuprolide } \\
\text { group }\end{array}$ & $\begin{array}{l}\text { LNG-IUD plus } \\
\text { Leuprolide group: } \\
\text { intermenstrual } \\
\text { bleeding }(69.6 \%) \\
\text { acne }(56.5 \%) \text {, oily } \\
\text { skin }(69.6 \%) \\
\text { leuprolide group: } \\
\text { breast tenderness } \\
(37.5 \%) \text {, headache } \\
(32.5 \%) \text {, vaginal } \\
\text { spotting }(27.5 \%) ;\end{array}$ \\
\hline
\end{tabular}

$\mathrm{AE}=$ adverse event, $\mathrm{LNG}-\mathrm{IUD}=$ levonorgestrel-intrauterine device, $\mathrm{VAS}=$ visual analogue scale, $\mathrm{IM}=$ intramuscular, $\mathrm{SC}=$ subcutaneous, $\mathrm{NR}=$ not reported, $\mathrm{DEXA}=$ dual-energy $\mathrm{x}$-ray absorptiometry, TESP= total endometriosis severity profile score 


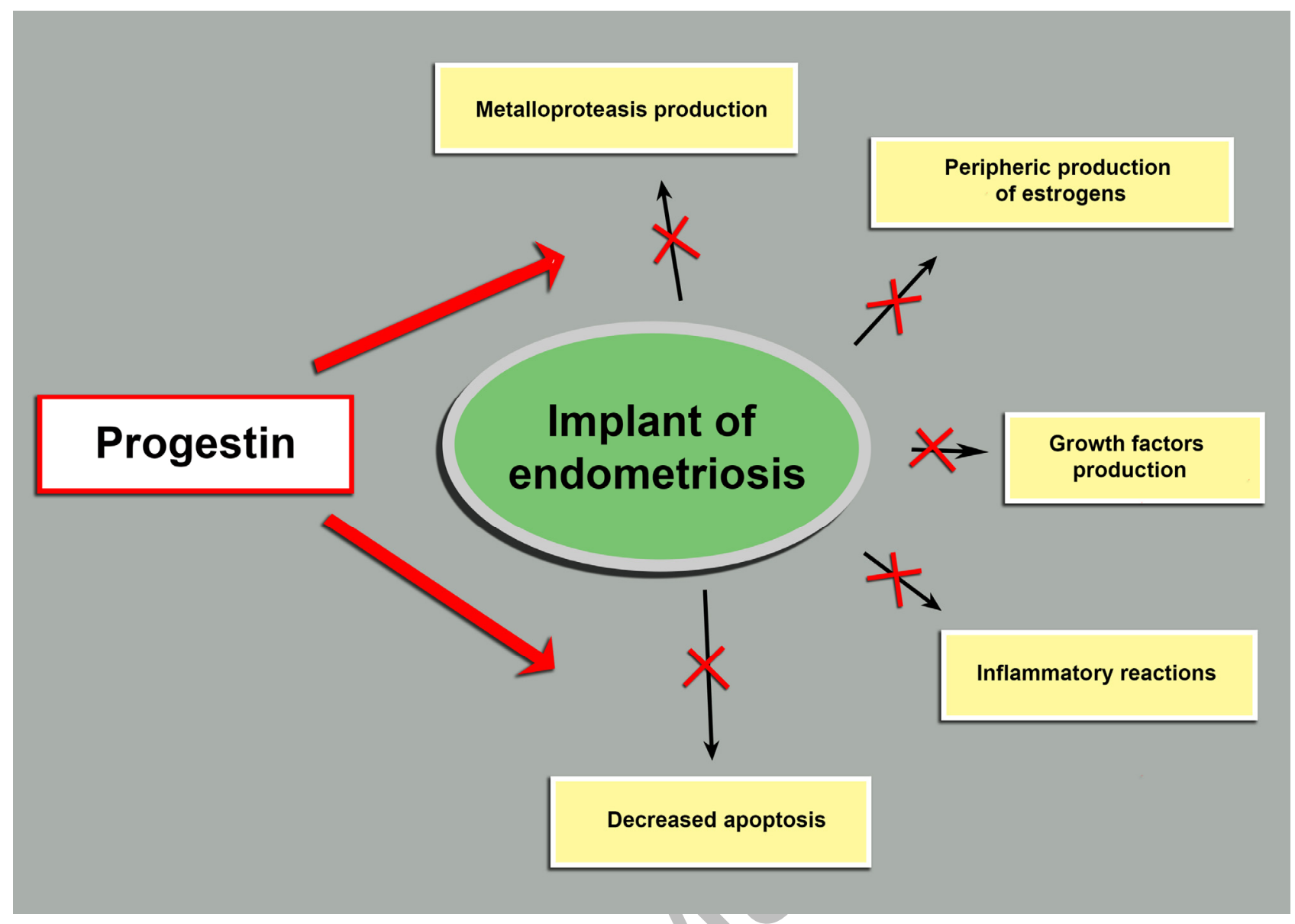

Figure 1. Progestins reduce the frequency and increase the amplitude of gonadotropinreleasing hormone (GnRH) pulsatile release, decreasing the secretion of follicle stimulating hormone (FSH) and luteinizing hormone (LH). They lead to suppress the ovarian steroidogenesis with consequent anovulation and low serum levels of endogenous ovarian steroids. Moreover, progestins have anti-inflammatory effect, and directly act on ectopic endometrial cells, reducing the expression of matrix metalloproteinases. All these effects reduce the implantation and progression of endometriotic lesions. 

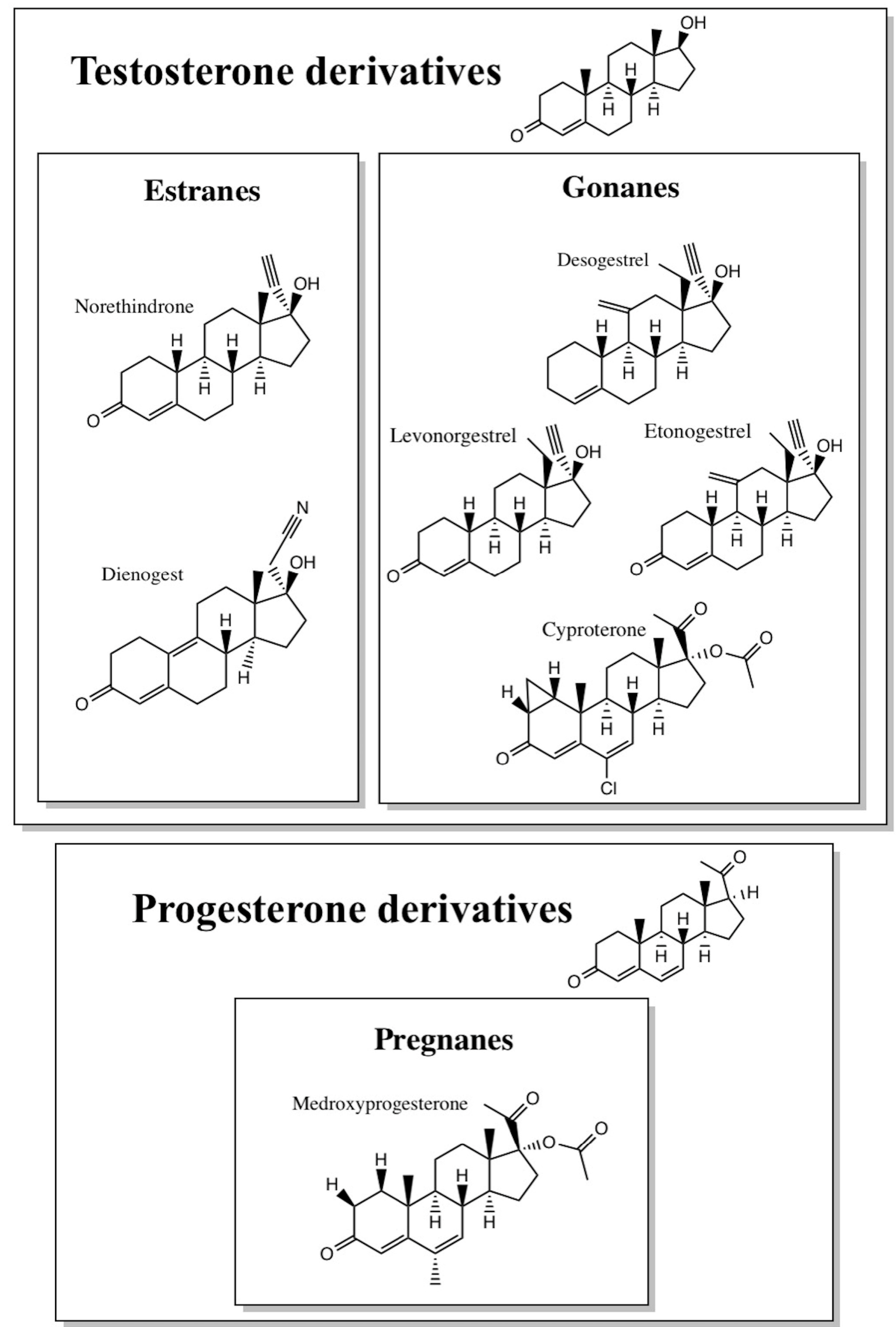

Figure 2. Besides the natural progestin, progesterone, there are different classes of progestins. The main progestins used in treatment of endometriosis belong progesterone derivatives (pregnanes), testosterone derivatives (estranes and gonanes) and spironolactone derivatives. 